\title{
VIVES
}

DISCUSSION

PAPER

N ${ }^{\circ} 61$

OCTOBER 2017

\section{What Drives Labor Market Polarization in Advanced Countries? The Role of China and Technology}

Koen Breemersch

VIVES (KU Leuven)

Jože P. Damijan

University of Ljubljana; and VIVES (KU Leuven)

Jozef Konings

VIVES (KU Leuven); Nazarbayev University; and University of Ljubljana 


\title{
What Drives Labor Market Polarization in Advanced Countries? The Role of China and Technology'
}

\author{
Koen Breemersch ${ }^{2}$
}

Jože P. Damijan

Jozef Konings ${ }^{4}$

\begin{abstract}
This paper explores the effects of offshoring, technology and Chinese import competition on labor market polarization in European countries. We find that polarization occurs mostly as a result of polarization within individual industries, while the reallocation of employment away from less polarized industries towards more highly polarized industries contributed only about one third of the total change. We find that both technological change and Chinese net import competition contributed to labor market polarization, but that they did so in distinct ways. In European manufacturing industries, ICT adoption explains a third of within-industry polarization, while Chinese net import competition contributed to a much smaller extent. The process of between-industry polarization is driven by widespread deindustrialization and servitization in developed countries. We find that Chinese net import competition explains about a fifth of the employment decline in lowly-polarized manufacturing industries and was thus an important driver of the reallocation of labor within economies away from lowly polarized manufacturing industries. We present tentative evidence that employment grew faster in initially highly polarized service industries. Moreover, these industries appear unaffected by their indirect IO-exposure to Chinese net import competition, while this was not the case for initially lowly polarized service industries. While polarization patterns in different European labor markets show considerable heterogeneity, labor market institutions seem to be insufficient to explain these cross-country differences.
\end{abstract}

\footnotetext{
${ }^{1}$ This research received funding by the Organisation for Economic Cooperation and Development, contract no. 500038766. We thank G. Montt, G. Quintini, S. Broecke, M. Vandeweyer, M. Squicciarini, L. Marcolin, C. Webb, N. Corry, A. Bassanini, M. Meza-Essid, G. Bejan, J. Baker, A. Hijzen, P. Falco, H. Vandenbussche and J. Van Hove and two anonymous referees for useful comments and suggestions. We are also grateful for comments by the participants of two meetings at the OECD (Meeting of the Committee on Industry, Innovation and Entrepreneurship; and Joint meeting of the Working Party on Industry Analysis and of the Working Party on the Globalisation of Industry). All views expressed in this paper are those of the authors and do not necessarily reflect those of the OECD.

${ }^{2}$ University of Leuven; VIVES

${ }^{3}$ University of Ljubljana; VIVES; and University of Leuven

${ }^{4}$ Nazarbayev University, Astana; and University of Leuven; VIVES; and University of Ljubljana
} 


\section{Introduction}

One of the most notable developments in labor markets in the last two decades is the so-called "polarization" of employment, with employment growth "polarizing" into relatively high-skill, high-wage jobs and low-skill, lowwage jobs. In this process, the middle of the employment distribution in terms of skills and wages, consisting mainly of the routine jobs, has been hollowed out producing a typical U-shaped pattern of labor market dynamics in most advanced countries. This labor market evolution has puzzled researchers as it ran in contrast with the existing theories. One of the most broadly accepted theories of skill-biased technological change predicts a shift in demand towards more educated workers, but not towards low-skilled workers. It thus cannot explain the U-shaped shift in labor demand.

The literature has so far identified three complementary explanations for the observed labor market developments. First, Autor, Levy and Murnane (2003) stress the importance of the ongoing automation and offshoring of middleskilled "routine" tasks that used to be performed primarily by workers with moderate education (such as clerical and craft occupations). As these routines are sufficiently well defined, they can be carried out successfully by either a computer executing a program (automation) or by less-educated labor in developing countries. Brynjolfsson and McAfee (2014) predict that in the "second machine age" the growth in productivity has been decoupled from jobs and income as in the digital economy a set of goods and services can be provided at a cost that is often close to zero. New technology does not inevitably reduce the overall demand for labor, but shifts demand to different kinds of work contributing to the U-shaped pattern of labor market evolution. So far, most research has focused on this technological channel triggered by innovation and automation (e.g. Autor, 2015). Goos et al. (2014) show that the main effect comes from 'routine biased technological change', while offshorability of routine tasks has also contributed to polarization. However, Goos et al. use a subjective indicator taken from surveys to capture the 'offshorability of tasks' rather than a trade-based measure of offshoring. Moreover, their measure does not vary over time, which arguably might be important when analyzing polarization. Oldenski (2014) analyzes the impact of offshoring on polarization in the United States using a newly constructed measure, based on the total sales by a foreign affiliate of a U.S. multinational as a share of its total sales. While not much of an effect is found on average wages and employment, significant effects of both offshoring and technological change (proxied by the use of ICT) are found on polarization patterns in the U.S.

A second explanation highlights the importance of globalization and offshoring as an essential source of changes in the labor market structure in advanced countries (see Blinder, 2009a, 2009b). Routine jobs such as assembly lines are being progressively offshored to lower-wage countries, which diminishes demand for labor in the middle of the wage distribution. On the other side, increased competition from low-wage countries with their own products in the low-tech and middle-tech industries aggravates these pressures on middle-wage jobs in advanced countries. These pressures have intensified in particular after China's entry into the WTO in 2001. Since the entry of China into the WTO in 2001 until the crisis in 2008, U.S. and EU manufacturing employment declined by 3.5 and 3.6 million units, respectively. Autor et al. (2013) estimate that about a quarter of the aggregate decline in U.S. manufacturing employment is due to the rise of Chinese import penetration. The findings of Donoso et al. (2014), Dauth et al. (2014) and Balsvik et al. (2013) confirm that the Spanish, German and Norwegian local labor markets that are specialized in industries competing with Chinese imports, underwent a similar fate. While it is clear that globalization has had an important impact on this process of deindustrialization, not much evidence exists on how globalization, deindustrialization and polarization are related. In a recent contribution, Keller and Utar (2016) linked the rise in Chinese imports to the decline in Danish middle-paid manufacturing jobs, which has further aggravated employment polarization. As workers are pushed out of middle-paid employment in manufacturing, they transfer to low-wage services or high-wage employment. These effects hold when controlling for offshoring and technology, suggesting that Chinese import competition operates separately from these channels and is an alternative force of labor market 
polarization. Overall, the estimates suggest that Chinese import competition accounts for about a fifth of total midpaid employment decline in the Danish national labor market.

Finally, a third explanation suggests there is a link between job polarization and wage inequality. Studies by Manning (2003) and Mazzolari and Ragusa (2013) stress that the increased polarization in the income distribution in the United States and the United Kingdom may have affected the labor market. A surge in the share of income going to the rich may have contributed to the shift in demand for low-skill labor to provide "services to the rich".

In this paper, we focus on the relative importance of two competing explanations for the observed pattern of polarization in advanced countries - globalization versus technological change. Here, globalization is captured by two different variables, the offshoring and Chinese import competition. Also, the impact of technology on polarization was studied using two measures $-\mathrm{R} \& \mathrm{D}$-induced and ICT-induced technological change. In addition to this, we also explore whether differences in labor market institutions can help explain the discrepancy in polarization patterns between countries. In order to do so, we use disaggregated industry-level data for a large sample of 19 European OECD countries for the period 1997-2010. This enables us to study differential labor market developments in countries that have been engaged in offshoring on both sides. Arguably, in advanced EU countries engaged in outward foreign direct investment (FDI) labor market polarization will be more pronounced than in countries receiving FDI and consequent increase in demand for routine jobs. We will explore this heterogeneity in labor market polarization between the different countries that make up our sample. We also contribute to the literature by simultaneously examining the effects of offshoring, technology and Chinese import competition in a large crosscountry sample rather than at the individual country level. Finally, we analyze how labor market institutions may affect polarization patterns. These institutions could affect the relative wages of different skill groups. Therefore, we would expect that the impact of both technological progress and the emergence of GVCs may be different depending on the type of regulations and wage setting institutions that prevail in various countries. To perform this analysis we analyze both manufacturing industries and private industries other than manufacturing. This allows us to tease out various relationships between the degree of involvement in GVCs, technological change, Chinese import competition, institutions and polarization at the industry level.

Our main findings can be summarized as follows: First, polarization is a phenomenon that is predominantly driven by polarization within individual industries. The reallocation of employment away from lowly polarized industries with relatively more mid-skill jobs, such as manufacturing, towards highly polarized industries with relatively more low- and high-skill jobs contributes about one third to the overall polarization. Second, both technological change and Chinese import competition have contributed to labor market polarization. However, they have affected the labor market in disparate ways. Our estimates show that ICT adoption in manufacturing industries can explain around a third of the relative increase of high-paid employees in manufacturing, while Chinese net import competition accounts for only four percent of the total effect. However, in line with findings elsewhere in the literature Chinese net import competition explains about a fifth of the overall decline of employment in manufacturing industries or a loss of 944.000 manufacturing jobs across Europe, while technology did not have a clear effect. Hence, Chinese net imports are particularly relevant in explaining the reallocation of labor in the economy away from lowly polarized manufacturing industries. Moreover, our estimates indicate that initially more polarized service industries grew faster than their less polarized counterparts. Third, we present tentative evidence that employment grew faster in initially highly polarized service industries. Less polarized service industries also suffered indirectly from their exposure to the Chinese net import penetration shock in manufacturing, but their more polarized counterparts did not. These different employment trends explain how deindustrialization and the servitization of the economy led to greater polarization in the overall labor market. Fourth, we find no direct proof that labor market institutions are behind the heterogeneous patterns of polarization in European labor markets. Since we do not have data on wage polarization, our findings do not exclude that labor market institutions are relevant in affecting wage polarization. Nevertheless, 
our results suggest that there is ample scope for policies such as skill-development programs, activation policies and sufficient social protection to facilitate smooth transition processes for affected workers.

The remainder of the paper is structured as follows. In the next section we discuss the data and provide some stylized facts on job polarization in various OECD countries. In section 3 we perform an econometric analysis to assess to what extent polarization is correlated with technical change, Chinese import competition and the emergence of GVCs. We focus primarily on polarization that occurs within a given industry but also analyze polarization that has occurred as a result of the reallocation of employment to more highly polarized industries. Section 4 concludes the paper.

\section{Data and Basic Facts}

\subsection{Occupations and Polarization}

Our main data source to study the dynamics of labor polarization in the European Union is the harmonized European Labor Force Survey (ELFS) provided by EUROSTAT, which provides very detailed employment statistics. The data contains information from 1995 to 2010 on employment status, the International Standard Occupational Classification (ISCO) codes, gender, and other major labor market characteristics of the workforce for each NACE two-digit industry within 19 European countries ${ }^{5}$. Since the data do not suffice to carry out an analysis on wage polarization, our analysis is entirely concentrated on the issue of employment polarization. We follow Autor and Dorn (2013) and Goos et al. (2014) and order occupations by average wage level. Having data on a detailed sectoral level rather than the more aggregated country level lends us the ability to account for the different degrees of technological change, product market competition and hence productivity growth which have an impact on demand for different skills. An additional appealing feature of our data set is the possibility to explore the heterogeneity between and within sectors.

In Table 1 we take a first look at the existence of polarization during the period from 1997 to $2007^{6}$. The table shows the long-term pattern of labor market polarization in terms of employment shares by different occupational groups at the national level, averaged across all countries for which data were available for the entire period.

\footnotetext{
5 These countries are Austria, Belgium, Denmark, Germany, France, Finland, Greece, Portugal, Spain, The Netherlands, Great-Britain, Slovenia, Slovakia, Sweden, Czech Republic, Italy, Hungary and Ireland.

${ }^{6}$ In 2011 the new ISCO08 codes were implemented and the data suffers from a structural break that cannot be overcome through concordance procedures. 2010 is thus chosen as the endpoint of our analysis here.
} 
Table 1: Average Share of Employment by major occupational groups, 1997-2007 (Europe)

\begin{tabular}{|c|c|c|c|c|}
\hline & & & \%point change & RTI \\
\hline Occupation (ISCO) & 1997 & 2007 & $1997-2007$ & \\
\hline low Paying & 23.6 & 25.4 & 1.8 & \\
\hline Elementary occupations & 10.2 & 10.7 & 0.5 & 2.11 \\
\hline Service and Sales Workers & 13.5 & 14.8 & 1.3 & -0.65 \\
\hline Middle Paying & 46.4 & 39.9 & -6.5 & \\
\hline Clerical Support Workers & 15.4 & 12.7 & -2.7 & 1.59 \\
\hline Craft and Related Trades Workers & 17.5 & 14.2 & -3.3 & 1.53 \\
\hline Plant and Machine Operators & 13.5 & 13.0 & -0.5 & 1.85 \\
\hline High Paying & 30.0 & 34.7 & 4.7 & \\
\hline Technicians and Associate Professionals & 15.1 & 17.9 & 2.8 & -0.57 \\
\hline Professionals & 9.8 & 11.3 & 1.5 & -1.31 \\
\hline Legislators, senior officials and managers & 5.1 & 5.5 & 0.4 & -1.39 \\
\hline
\end{tabular}

Middle-paid occupations have declined as a share of total employment (-6.5 percentage points), while low-paid (+1.8 percentage points) and high-paid (+4.7 percentage points) occupations have gained as a share of total employment. Henceforth we shall refer to the increase of low-paid occupations relative to middle-paid occupations as low-paid employment polarization and the increase of high-paid occupations relative to mid-paid occupations as high-paid employment polarization. Table 1 also reports the Routine Task Index (RTI) used in Goos et al. (2014) and averaged by the eight occupational categories that we use. The higher the index, the more routine the tasks are considered to be. It is clear that in the middle-paid occupations this RTI index is highest, suggesting that these middle-paid occupations can be mostly considered as routine tasks. Routine tasks are more exposed to skill biased or routine biased technological change. They are also subject to offshoring because of changing relative prices and international specialization along GVCs. Table 1 reports averages across various countries. However, by using averages a lot of heterogeneity in polarization across countries is masked. This is demonstrated in figure 1 . The figure shows long-run polarization across EU countries between 1997 and 2007. In accordance with table 1, we have grouped the employment shares of the eight occupational categories into three broad occupational groups reflecting their wage structure: low-paid, middle-paid and high-paid. The figure shows the prevalence of labor market polarization, but at the same time there are a number of noticeable differences in patterns and magnitude across countries. For instance, the Czech Republic has undergone a decline in the share of low-paid occupations, rather than a rising share. Other countries follow the typical polarization pattern, but the growth rate of the various occupational shares varies between them. Although the United States is not included in our sample, statistics in the literature of this country have demonstrated that the trend is also observed along the dimensions we would expect (Katz and Margo, 2014). 
Figure 1: Heterogeneity in polarization, European countries, 1997-2007

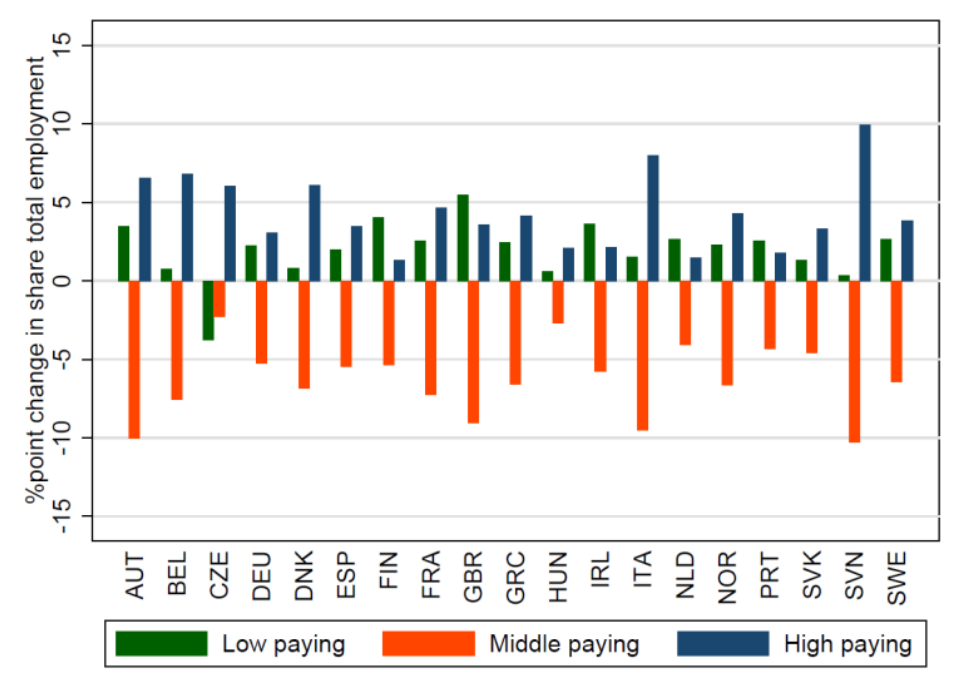

Source: Authors' calculations based on ELFS

\subsection{Within-sector and between-sector polarization}

The increase in polarization that we observe at the national level can occur as a result of polarization within individual industries or employment shifting away from industries that are initially lowly polarized to industries that are more polarized. The latter type of polarization might be particularly of interest given the decline of manufacturing and the shift towards services in developed economies.

In table 2 we report the average polarization by NACE one-digit industry in 1997 and $2007^{7}$ and the average change in employment share. Employment polarization is computed by dividing the sum of low- and high-skilled employees by the total number of employees in an industry. As before, we divide occupations into skill groups in accordance with Goos et al. (2014) ${ }^{8}$. The table reveals that polarization has risen in nearly every industry. Interestingly, the table also shows that there are large differences in the average level of polarization between the different industries. For instance, manufacturing is a relatively low-polarized industry whereas real estate and business services is on average amongst the more polarized industries in Europe. Deindustrialization also led to employment shifting away from the former, while the share in aggregate employment of the latter grew.

To understand the contribution of within-industry polarization and structural shifts between industries, we decompose aggregate polarization of a country $c$, Polar $_{c}$, into a within- and between-industry term in equation (1) as also done by Goos et al. (2014). We also account for differences between the relative contributions of high- and lowskilled employees to overall polarization in our decomposition. In this way we can test whether the process of polarization is fully symmetrical at the high- and low-paying end of the labor market, as our decomposition should show similar contributions of both groups of employees. We then analyze the relevance of each factor. In our

\footnotetext{
${ }^{7}$ We chose 1997 as the initial year because data for some countries are missing in 1995 and 1996. Since observations for Slovakia in the ELFS start from 1998 onwards, we use 1998 to compute the averages of that country for 1997 . We set 2007 as the final year of our analysis since the NACE industry codes changed in 2008 causing a structural break in the series.

${ }^{8}$ See table 1.
} 
econometric analysis in section 3 we mostly focus on polarization in both two-digit manufacturing industries and one-digit non-manufacturing industries. For the purposes of analyzing broad shifts across sectors in this section, onedigit industries are preferable.

Table 2: Average polarization and change in aggregate employment share by industry in 1997 and 2007

\begin{tabular}{llccccc}
\hline \hline Industry & \multicolumn{3}{c}{$\begin{array}{c}\text { Fraction of high- and low-paid } \\
\text { employees }\end{array}$} & \multicolumn{2}{c}{$\begin{array}{c}\text { Change in the share of overall } \\
\text { employment }\end{array}$} \\
\cline { 2 - 7 } & 1997 & 2007 & $\boldsymbol{\Delta}$ & 1997 & 2007 & $\boldsymbol{\Delta}$ \\
\cline { 2 - 7 } Agriculture & 0.49 & 0.52 & $\mathbf{0 . 0 3}$ & 0.01 & 0.01 & $\mathbf{- 0 . 0 0}$ \\
Mining & 0.30 & 0.34 & $\mathbf{0 . 0 4}$ & 0.01 & 0.01 & $\mathbf{- 0 . 0 0}$ \\
Manufacturing & 0.32 & 0.37 & $\mathbf{0 . 0 5}$ & 0.26 & 0.22 & $\mathbf{- 0 . 0 4}$ \\
Electricity, gas, water supply & 0.41 & 0.50 & $\mathbf{0 . 0 9}$ & 0.02 & 0.01 & $\mathbf{- 0 . 0 1}$ \\
Construction & 0.25 & 0.27 & $\mathbf{0 . 0 2}$ & 0.08 & 0.08 & $\mathbf{0 . 0 0}$ \\
Wholesale and retail trade & 0.67 & 0.71 & $\mathbf{0 . 0 4}$ & 0.14 & 0.15 & $\mathbf{0 . 0 1}$ \\
Hotels and restaurants & 0.91 & 0.91 & $\mathbf{- 0 . 0 0}$ & 0.04 & 0.05 & $\mathbf{0 . 0 1}$ \\
Transport and Communication & 0.33 & 0.37 & $\mathbf{0 . 0 4}$ & 0.08 & 0.07 & $\mathbf{- 0 . 0 1}$ \\
Financial intermediation & 0.54 & 0.64 & $\mathbf{0 . 1 0}$ & 0.04 & 0.03 & $\mathbf{- 0 . 0 1}$ \\
Real Estate and business services & 0.71 & 0.78 & $\mathbf{0 . 0 7}$ & 0.07 & 0.10 & $\mathbf{0 . 0 3}$ \\
Public administration & 0.67 & 0.74 & $\mathbf{0 . 0 7}$ & 0.08 & 0.08 & $\mathbf{- 0 . 0 0}$ \\
Education & 0.77 & 0.82 & $\mathbf{0 . 0 5}$ & 0.03 & 0.03 & $\mathbf{0 . 0 0}$ \\
Health and Social work & 0.88 & 0.90 & $\mathbf{0 . 0 2}$ & 0.11 & 0.12 & $\mathbf{0 . 0 1}$ \\
Other Services & 0.72 & 0.75 & $\mathbf{0 . 0 3}$ & 0.04 & 0.04 & $\mathbf{0 . 0 0}$ \\
\hline \hline
\end{tabular}

Source: Authors' calculations based on ELFS data. Simple (unweighted) averages computed across all countries in the sample.

$$
\begin{aligned}
\Delta \operatorname{Polar}_{c} & =\underbrace{\sum_{i} \Delta \operatorname{Polar}_{\mathrm{ic}} \bar{S}_{\mathrm{ic}}}_{\text {Within-term }}+\underbrace{\sum_{i} \Delta S_{\mathrm{ic}} \overline{\operatorname{Polar}}_{\mathrm{ic}}}_{\text {Between-term }} \\
& =\underbrace{\sum_{i} \Delta L \operatorname{Pol}_{i c} \bar{S}_{\mathrm{ic}}}_{\begin{array}{c}
\text { Within-low-paid } \\
\text { polarization term }
\end{array}}+\underbrace{\sum_{i} \Delta \operatorname{HPol}_{i c} \bar{S}_{\mathrm{ic}}}_{\begin{array}{l}
\text { Within-high-paid } \\
\text { polarization term }
\end{array}}+\underbrace{\sum_{i} \Delta S_{\mathrm{ic}} \overline{L P O L_{l c}}}_{\begin{array}{c}
\text { Between-low-paid } \\
\text { polarization term }
\end{array}}+\underbrace{\sum_{i} \Delta S_{\mathrm{ic}} \overline{H P O L_{l c}}}_{\begin{array}{c}
\text { Between-high-paid } \\
\text { polarization term }
\end{array}}
\end{aligned}
$$

Where Polar $_{i c}$ is the within-industry polarization, $L P O L_{i c}$ is the number of low-skilled employees relative to the total number of employees, $H P O L_{i c}$ is the number of high-skilled employees relative to the total number of employees and $S_{i c}$ is the employment share of the industry relative to total employment in all considered industries of country $c$. The change is computed over the period of 1997 to 2007. In figure 3 we show the results of this decomposition by country and list the average for the European countries in the middle of the graph. Countries are sorted according to the percentage point rise in total polarization, $\Delta$ Polar $_{c}$, which is reported as an integer number by country.

The existence of heterogeneity in cross-country polarization patterns that we reported earlier is again emphasized in the results of the decomposition. Moreover, both the increase in polarization within individual industries and the reallocation of employment towards more highly polarized industries is causing overall national polarization. However, the within-industry component is the most important contributor to overall polarization. On average, it explains $68 \%$, or 4.3 percentage points, of the 6.3 percentage points increase of low- and high paid employment in total employment in the European countries. Generally within-industry high-paid employment polarization 
contributes the largest overall fraction to total polarization across all countries. In contrast, within-industry low-paid employment polarization varies considerably across the different countries. In eight of the nineteen reported countries in our sample it has exerted a downward pressure on overall polarization. This suggests that employment polarization has not occurred symmetrically for low- and high-paid employment across all labor markets of Europe.

Figure 3: Within/between-sector decomposition of polarization, European countries, 1997-2007

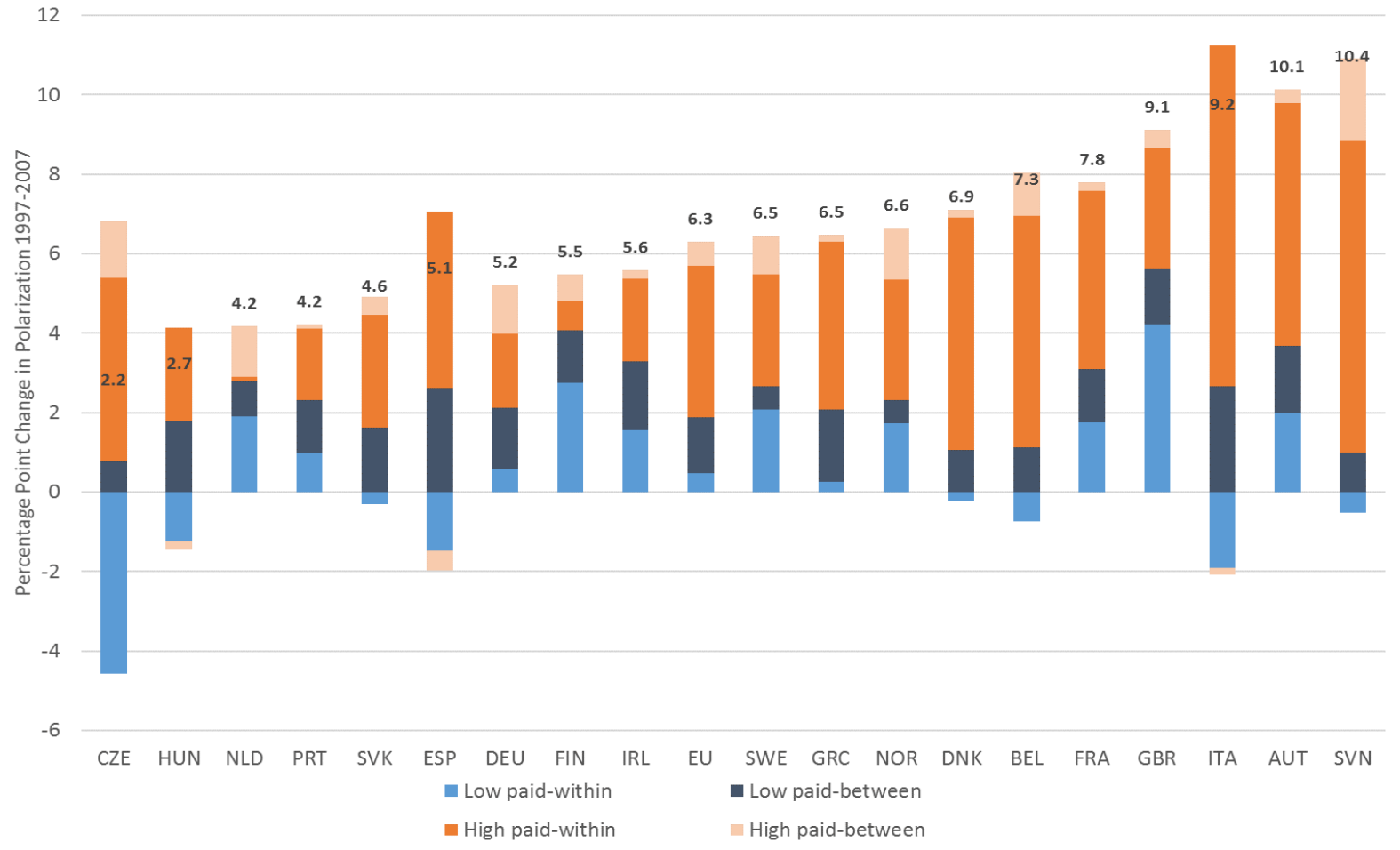

Note: Total percentage point increase in polarization ratio by country expressed as integer number Source: Authors' calculations based on ELFS

The average contribution of each sector to the overall within-industry component of polarization is examined in table 3. Similar to what was reported in table 2, we find that almost all industries are contributing positively to overall within-industry polarization and this is generally driven by the high-paid within-industry employment polarization component. This implies that within-sector polarization persistently features across all industries of the economy rather than being limited to a few individual industries. Although there is some variation across countries in the general contribution of each industry to the total within-sector polarization term, manufacturing and wholesale and retail trade generally appear as the largest overall contributors9. Meanwhile, the reallocation of employment away from manufacturing as a result of deindustrialization in high-income countries and towards industries such as business services and health and social work drives the between-industry term. Hence, based on this evidence,

${ }^{9}$ We have done the same within/between-decomposition at the manufacturing level. There, the within-industry term explains around $92 \%$ of total polarization on average, leaving little to be explained by reallocation of employment between the individual manufacturing industries of a country. 
manufacturing plays a prevalent role in explaining overall polarization. Moreover, as will be shown presently, manufacturing has also been highly susceptible to Chinese import competition, offshoring and technological change.

Table 3: Average individual sector contributions to within/between decomposition, European countries, 1997-2007

\begin{tabular}{|c|c|c|c|c|c|c|c|}
\hline \multicolumn{4}{|c|}{ Within } & \multicolumn{4}{|c|}{ Between } \\
\hline Industry & Low-paid & High-paid & Total & Industry & Low-paid & High-paid & Total \\
\hline Hotels \& Restaurants & -0.030 & 0.008 & -0.023 & Manufacturing & -0.402 & -1.005 & -1.407 \\
\hline Mining & 0.003 & 0.017 & 0.020 & Financial Intermediation & -0.013 & -0.231 & -0.244 \\
\hline Agriculture & -0.029 & 0.086 & 0.057 & Public Administration & -0.093 & -0.114 & -0.206 \\
\hline Other Services & -0.033 & 0.141 & 0.107 & Electricity, gas, water & -0.032 & -0.150 & -0.182 \\
\hline Electricity, gas, water & -0.028 & 0.145 & 0.117 & Agriculture & -0.043 & -0.118 & -0.161 \\
\hline Education & -0.013 & 0.166 & 0.153 & Transport\&Communication & -0.047 & -0.085 & -0.131 \\
\hline Construction & -0.043 & 0.200 & 0.157 & Mining & -0.023 & -0.40 & -0.063 \\
\hline Health\&Social work & 0.345 & -0.133 & 0.212 & Education & 0.026 & 0.024 & 0.050 \\
\hline Transport\&Communication & 0.266 & 0.0383 & 0.304 & Other Services & -0.001 & 0.072 & 0.071 \\
\hline Financial Intermediation & 0.004 & 0.385 & 0.389 & Construction & 0.153 & 0.069 & 0.222 \\
\hline $\begin{array}{l}\text { Real Estate and Business } \\
\text { Services }\end{array}$ & 0.127 & 0.401 & 0.528 & Wholesale\&Retail trade & 0.336 & 0.151 & 0.487 \\
\hline Public Administration & -0.021 & 0.588 & 0.567 & Hotels \& Restaurants & 0.645 & 0.055 & 0.699 \\
\hline Wholesale\&Retail trade & 0.202 & 0.366 & 0.568 & Health\&Social work & 0.253 & 0.428 & 0.681 \\
\hline Manufacturing & -0.058 & 1.191 & 1.133 & $\begin{array}{l}\text { Real Estate and Business } \\
\text { Services }\end{array}$ & 0.653 & 1.532 & 2.185 \\
\hline Total average contribution & 0.467 & 3.27 & 4.290 & Total average contribution & 1.41 & 0.589 & 2.002 \\
\hline
\end{tabular}

Note: Simple (unweighted) averages computed across all countries in the sample.

Source: Authors' calculations based on ELFS data.

\subsection{Technological change, Global Value Chains and Institutions}

To capture technological change or innovation we rely on two different proxies. First, we use the R\&D intensity of a sector taken from the OECD statistics database (OECD, 2016). This variable relates the R\&D expenditure in a sector $i$ of country $c$ to the value added, $V A_{i c t}$ that is generated in that same industry and is formally defined as:

$$
R \& D \text { Intensity }{ }_{i c t}=\frac{R \& D_{i c t}}{V A_{i c t}} .
$$

The use of R\&D as a proxy for technological change is predicated on a rich literature that has aimed to relate process and product innovation at the firm-level to employment changes. Specifically, Klette and Forre (1998) and, more 
recently, Bogliacino et al. (2012) both used R\&D expenditure to proxy for innovation. Interestingly, Bogliacino et al. also found that $R \& D$ as a proxy for innovation not only mattered for firms in manufacturing industries but also for firms active in services industries. This strengthens our belief that $R \& D$ expenditure can also be used as a trustworthy proxy for technological innovation in non-manufacturing industries. In light of the findings of Goos et al. (2016), we use the ICT capital services per hour worked, $I C T_{i c t}$, from EU Klems as an additional indicator of technological change. Goos et al. (2016) show that there is a positive correlation between the intensity of ICT capital use and the measured polarization within the industry. In contrast with R\&D Intensity, which is a measure of technological innovation particularly relevant within manufacturing, ICT capital intensity is a measure of technology adoption that shows large variation both across manufacturing and non-manufacturing industries.

As an indicator of the integration of an industry in GVCs and hence the likelihood that tasks are more easily 'offshorable', we use the foreign value added share embedded in the gross exports of each industry and in each country:

$$
\text { OFFSH }_{\text {ict }}=\frac{\text { FVA Exports } \text { sict }_{\text {. }}}{\text { Exports }_{\text {ict }}}
$$

This variable is collected from the 2015 version of OECD and WTO (2015)'s Inter-Country Input-Output (ICIO)

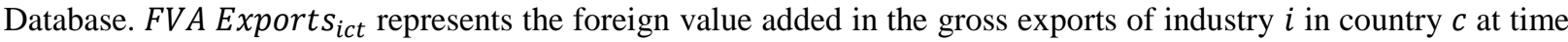
$t$ and Exports Ect $_{i c}$ are the gross exports of that same industry. A higher value indicates that an industry relies more on international specialization and hence international fragmentation of the production process, reflecting comparative advantages across industries and countries ${ }^{10}$.

As a measure of Chinese net import penetration we use the share of Chinese net imports in total industry domestic absorption ${ }^{11}$ :

$$
\text { Net Imp. pen } n_{\text {ict }}^{C H N}=100 *\left(\frac{I M P_{i c t}^{C H N}}{\text { Dom.abs }_{i c t}}-\frac{E X P_{i c t}^{C H N}}{\text { Dom.abs }_{i c t}}\right) \text {, }
$$

calculated on the basis of the WIOD database (Timmer et al., 2015). A positive value indicates that an industry is mostly exposed negatively to China through import competition while a negative value shows that China offers new export opportunities for that industry ${ }^{12}$. In figure A1 in appendix A, we present the change in Chinese (net) import penetration from 1995 to 2007 by country for the private economy and for manufacturing. The graph shows that manufacturing industries have been highly exposed to increasing Chinese import competition. Moreover, the change in exposure has varied across countries and this variation becomes even larger when considering the net import exposure. Central-European countries in particular have seen the largest increase in Chinese import penetration over the period.

Finally, we supplement our data with several additional country-level indicators on institutions from the OECD databases. In particular, we are interested in how labor market regulation, such as employment protection legislation,

${ }^{10}$ Data on the foreign component of value added in exports in the TiVA database is not available annually for all years of our sample. The data is available only for 1995, 2000, 2005, and the period 2008-2011. In order to improve the sample size, we have used linear interpolation to fill in the missing data. In table A1 in appendix A we show that both in terms of the initial levels of GVC involvement and the evolution over the time frame 1995 to 2010 countries show considerable heterogeneity.

${ }^{11}$ Domestic absorption reflects the domestic consumption of an industry's goods. It is computed as Dom.abs ict $=G O_{i c t}+I M P_{i c t}+$ $E X P_{i c t}$ Where $G O_{i c t}$ is the gross output of an industry $i$ of country $c$ during year $t, I M P_{i c t}$ are the imports by country $c$ during year $t$ of industry $i$ goods produced in other countries and $E X P_{i c t}$ are the exports by industry $i$ in country $c$ during year $t$.

${ }^{12}$ It would also be of interest to look at service imports into specific industries as these could equally affect employment. However, we do not have the necessary data at our disposal to explore the relevance of this type of this phenomenon on polarization. 
unionization, minimum wages, etc. might dampen or strengthen the evolution in job polarization. Therefore, we include the union density, the OECD index of employment protection legislation ${ }^{13}$ and an adjusted Kaitz index ${ }^{14}$. We present summary statistics for all main variables included in our regression samples in tables A2 and A3 of appendix A.

In table 4 we explore the relationship between the main components of our decomposition and offshoring (OFFSH), R\&D intensity, ICT and Chinese import penetration. We report the simple average of the change of employment and the change in within-sector polarization, the average level of offshoring intensity, ICT, R\&D intensity and Chinese import penetration across all countries in the sample ${ }^{15}$. Since data on R\&D intensity are unavailable for public sector industries, agriculture and mining, we only report statistics for non-agriculture and nonmining private industries. The table shows that manufacturing is strongly integrated in GVCs (high OFFSH), experiences strong Chinese import competition and also has high R\&D intensity. Chinese import competition and process innovation through $R \& D$ expenditure are relatively unimportant factors in non-manufacturing industries ${ }^{16}$. However, the level of ICT capital intensity varies substantially across non-manufacturing industries. The financial intermediation and the business service sector are particularly exposed to ICT-related technological change.

Table 4: The link between offshoring, technology and Chinese import penetration with within-industry polarization change (over period 1997-2007)

\begin{tabular}{l|cc|cccc}
\hline \hline Industry & $\Delta$ Polar & $\Delta e m p$. & OFFSH & R\&Dintensity & ICT & Net Imp. pen $_{\text {ict }}^{\text {CHN }}$ \\
\hline Construction & 2.62 & 0.60 & 23.78 & 0.14 & 2.43 & 0.18 \\
Electricity, gas, water supply & 10.14 & -0.34 & 26.12 & 0.37 & 18.12 & 0.07 \\
Financial intermediation & 8.99 & -0.23 & 9.787 & 0.42 & 69.19 & 0.03 \\
Hotels and restaurants & -0.40 & 0.61 & 16.45 & 0.00 & 5.96 & 1.27 \\
Manufacturing & 5.31 & -4.26 & 36.40 & 4.89 & 8.77 & 1.76 \\
Real estate and business serv. & 5.15 & 2.51 & 14.34 & 1.00 & 24.13 & 0.16 \\
Transport and communication & 3.35 & -0.34 & 20.74 & 0.46 & 19.00 & 0.47 \\
Wholesale and retail trade & 3.09 & 0.70 & 14.59 & 0.23 & 9.71 & 0.30 \\
\hline \hline
\end{tabular}

Note: Simple (unweighted) averages computed across all countries in the sample Source: Author's calculations based on ELFS data

\section{Empirical framework and Results}

We first focus on within-industry polarization and then turn to polarization caused by the between-industry reallocation of labor. For each of these two types of polarization we first outline the empirical framework and then present our results.

${ }^{13}$ We take the index of strictness of employment protection for temporary contracts. We have also experimented with the employment protection legislation for temporary and fixed contracts, but the results do not change qualitatively.

${ }^{14}$ The Kaitz index is constructed as the ratio of the minimum wage over the average wage in a country $\mathrm{c}$ at time $\mathrm{t}$. The index is adjusted to reflect the absence of a federal minimum wage in several of the countries in the sample. We set the value of the index to zero when a formal minimum wage does not exist at any moment during year $t$.

${ }^{15}$ We no longer weight each observation according to the average employment level as in equation 1.

${ }^{16}$ Acemoglu et al. (2016) show that these industries are mostly indirectly exposed to Chinese import competition shocks through their industrial linkage with domestic manufacturing firms. 


\subsection{Within-industry polarization}

\subsubsection{Empirical Framework}

We specify two reduced form equations that include these three forces, one focusing on the share of workers $(N)$ in high-paid $(h)$ relative to middle-paid $(m)$ occupations, $\frac{N_{h}}{N_{m}}$; and the second one aiming at the share of workers in low-paid $(l)$ occupations to middle-paid $(m)$ ones, $\frac{N_{l}}{N_{m}}$. In this way we take into account that the within-industry polarization patterns have differed greatly at the high- and low-paying end of the labor market in line with our findings in section 2.2. We again order occupations according to average wage level in line with Goos et al. (2014). Through our specifications, we capture the observed within-industry polarization and correlate it to our indicators of technological change, offshoring and Chinese net imports ${ }^{17,18}$. Similar set-ups have been used by Autor and Dorn (2013), Oldenski (2014), Keller and Utar (2016) and others. Thus, we seek to estimate the following specifications and variations of them:

$$
\begin{gathered}
\ln \left(\frac{N_{h}}{N_{m}}\right)_{\text {ict }}=\alpha_{1}+\alpha_{2} \ln \text { OFFSH }_{i c t}+\alpha_{3} \ln R \& D \text { Intensity }_{\text {ict }}+\alpha_{4} \ln I C T_{i c t}+\alpha_{5} \text { Net Imp.pen } \text { Ict }_{i c t}^{C H N}+\alpha_{6} \boldsymbol{L}_{c t}+\theta_{i c}+\epsilon_{i c t} \\
\ln \left(\frac{N_{l}}{N_{m}}\right)_{\text {ict }}=\alpha_{1}+\alpha_{2} \ln \text { OFFSH }_{i c t}+\alpha_{3} \ln R \& D \text { Intensity } \text { ict }_{1}+\alpha_{4} \ln I C T_{i c t}+\alpha_{5} \text { Net Imp.pen } \text { I }_{i c t}^{C H N}+\alpha_{6} \boldsymbol{L}_{c t}+\theta_{i c}+\eta_{i c t}
\end{gathered}
$$

With subscript $i, c$ and $t$ referring to industry, country and year, respectively. $\theta_{i c}$ are countryxindustry fixed effects and $\epsilon_{i c t}$ and $\eta_{\text {ict }}$ are the error terms. These specifications allow us to analyze how the employment structure within industries has on average been affected by the change in technology, import competition and offshoring. We expect that $\alpha_{2}, \alpha_{3}, \alpha_{4}$ and $\alpha_{5}\left(\beta_{2}, \beta_{3}, \beta_{4}\right.$ and $\beta_{5}$ respectively) have a positive effect on the share of high- (low-)paid occupations on average. The dependent variables and $O F F S H$; ICT and $R \& D$ Intensity are measured in logarithms, which facilitates the interpretation of the coefficients as they refer to elasticities. Our regression specifications will be augmented with indicators of labor market institutions, indicated by the vector $\mathbf{L}$.

By including all available sectors in one specification, we stand to lose a large fraction of underlying variation which in turn would make it more difficult to find any statistical relationships in the data. We therefore report results for a detailed subsample of manufacturing industries defined at the NACE rev.1.1 two-digit level, while the other subsample consists of all non-manufacturing private industries defined at the NACE rev.1.1 one-digit level (excluding agriculture and mining). In section 2.2 we noted that polarization in manufacturing industries is almost entirely explained by within-sector polarization and that the sector has been highly exposed to the forces of technology and globalization. Given this difference in exposure between manufacturing and non-manufacturing industries, a separate analysis for each group of industries is helpful in establishing whether the role of offshoring, Chinese import competition and technology differed between manufacturing industries and non-manufacturing industries. Each observation is weighted by the share of sector employment in total private employment.

${ }^{17}$ In terms of equation 1 , we try and explain the $\Delta$ Polar term and use the industry shares as weights.

18 Our specifications suggests a straightforward link between the different regressors and the within-industry polarization dependent variables. However, rigidity in relative wages could interact with technological change and globalization to induce further job destruction for certain tasks. However, given the complexity of this issue we will not address it further here. 


\subsubsection{Within-industry Results}

We first estimate a specification without time fixed effects in columns (1) and (2) of table 5 to uncover the correlations in the data. Interestingly, both technology variables enter significantly thus indicating that both variables capture different aspects of technological change and are positively correlated with high-polarization in manufacturing industries. We do not find proof that involvement in GVCs through offshoring is linked to polarization. However, a one percentage point rise in Chinese net import competition is correlated with a 1.5 percent rise in high-paid employment polarization. The latter correlation shows that globalization has coincided with withinindustry polarization in manufacturing industries. We do not find empirical evidence that any of the three forces are associated with low-paid employment polarization, thus unveiling an asymmetry with which the forces affect employment polarization at the high and the low end of the pay-scale. One potential explanation for this asymmetry could be the discrepancy of within-industry low-paid employment polarization across European labor markets. We will explore this asymmetry across country groups in table 7 . We also find that the effect of labor market institutions is not strongly correlated with polarization.

In columns (3) and (4) we include a country-specific time trend in our specification. Given the structure of our data, the identification will now occur through industry-specific time variation that differs from the country trend. However, the accession of China to the WTO in 2001 triggered a rise in offshoring and Chinese imports, which any time trend will automatically capture. By including the trend we thus run the risk of being left with insufficient variation to identify our indicators of globalization ${ }^{19}$. The literature uses detailed industry level data to overcome this obstacle and ensure sufficient variation is available for proper identification. While our data offers the advantage of covering multiple countries, it comes at the price of having industry-level data at a more aggregated level. Nevertheless, we find that a rise in ICT capital services and Chinese net import penetration lead to an increase in high-paid employment polarization, but R\&D intensity no longer show a statistically significant relationship. Hence, our results suggest that the effect of ICT-induced technological change and Chinese import competition on highpaying employment polarization is more causal in nature. A ten percent increase in ICT-induced technological change causes a $1.28 \%$ increase in high-paid employment polarization, while a one percentage point increase in Chinese net import competition leads to a $1.2 \%$ rise in high-paid employment polarization.

\footnotetext{
${ }^{19}$ The use of linear interpolation to connect missing year data points of the offshoring measure also means that some variation allowing independent identification of the effect of offshoring on polarization is lost.
} 
Table 5: Explaining within-industry polarization using manufacturing sector data (NACE two digit) in the

\begin{tabular}{|c|c|c|c|c|}
\hline & $\begin{array}{l}\text { (1) } \\
\text { top }\end{array}$ & $\begin{array}{c}\text { (2) } \\
\text { bottom }\end{array}$ & $\begin{array}{l}\text { (3) } \\
\text { top }\end{array}$ & $\begin{array}{c}\text { (4) } \\
\text { bottom }\end{array}$ \\
\hline OFFSH & $\begin{array}{l}0.357 * * \\
(0.155)\end{array}$ & $\begin{array}{l}0.025 \\
(0.255)\end{array}$ & $\begin{array}{l}-0.075 \\
(0.135)\end{array}$ & $\begin{array}{l}-0.237 \\
(0.313)\end{array}$ \\
\hline R\&D intensity & $\begin{array}{c}0.092 * * * \\
(0.022)\end{array}$ & $\begin{array}{c}0.056 \\
(0.049)\end{array}$ & $\begin{array}{c}0.029 \\
(0.027)\end{array}$ & $\begin{array}{l}-0.013 \\
(0.031)\end{array}$ \\
\hline ICT & $\begin{array}{c}0.250 * * * \\
(0.040)\end{array}$ & $\begin{array}{c}0.113 \\
(0.094)\end{array}$ & $\begin{array}{l}0.128 * * \\
(0.054)\end{array}$ & $\begin{array}{c}0.003 \\
(0.077)\end{array}$ \\
\hline Net Imp.pen ${ }^{C H N}$ & $\begin{array}{c}0.015^{*} \\
(0.007)\end{array}$ & $\begin{array}{c}0.012 \\
(0.015)\end{array}$ & $\begin{array}{l}0.012 * * \\
(0.005)\end{array}$ & $\begin{array}{c}0.017 \\
(0.010)\end{array}$ \\
\hline Union Density & $\begin{array}{c}0.331 \\
(0.697)\end{array}$ & $\begin{array}{c}1.256 \\
(2.569)\end{array}$ & & \\
\hline EPL & $\begin{array}{c}0.008 \\
(0.078)\end{array}$ & $\begin{array}{r}-0.008 \\
(0.160)\end{array}$ & & \\
\hline Adjusted Kaitz index & $\begin{array}{c}-0.073 \\
(0.119)\end{array}$ & $\begin{array}{c}0.311 \\
(0.249)\end{array}$ & & \\
\hline Constant & $\begin{array}{l}-2.639 * * * \\
(0.604)\end{array}$ & $\begin{array}{l}-2.801 * \\
(1.330)\end{array}$ & & \\
\hline Observations & 1937 & 1932 & 2053 & 2048 \\
\hline Industry $\times$ Country FEs & Yes & Yes & Yes & Yes \\
\hline Country $\times$ Year FEs & No & No & Yes & Yes \\
\hline$R^{2}$ & 0.930 & 0.792 & 0.954 & 0.905 \\
\hline
\end{tabular}

Standard errors in parentheses ${ }^{*} p<0.10,{ }^{* *} p<0.05,{ }^{* * *} p<0.01$

Estimates based on manufacturing sectors (NACE two digit). Standard errors clustered at the country level. All variables are expressed in logs with the exception of the adjusted Kaitz index and labor union density. Observations are weighted. The dependent variable top is the ratio of high-paid employees over mid-paid employees. The dependent variable bottom is the ratio of low-paid employees over mid-paid employees. All results robust to excluding the petroleum and nuclear fuel industry.

Table 3 showed how the manufacturing industry in the EU on average accounted for $(100 \% * 1.133 / 4.290=) 26$ percent of overall within-industry polarization. Moreover, high-paid employment polarization was the major driver of manufacturing's within-industry polarization. Given our estimates, we can thus analyze how ICT-induced technological change and Chinese net import competition contributed to overall within-industry polarization. We therefore use the significant estimates that we obtained in column (3) to make predictions on the estimated high-paid within-industry polarization. We report our estimates as a relative fraction of overall observed high-paid employment polarization within manufacturing ${ }^{20}$. Our predictions explain on average around 37 percent of overall within-industry polarization observed in the EU. However, the estimates strongly vary across countries, explaining for instance only 5 percent of high-paid employment polarization in Slovenian manufacturing industries while explaining 76 percent of the same type of polarization for German manufacturing industries. A common factor across all countries is the dominant role of ICT induced technical change, which explains on average around 33 percent of the high-paid

\footnotetext{
${ }^{20}$ We exclude countries where data on ICT or Chinese net import competition was missing in the beginning or end year. Additionally, Hungary, Czech Republic and the Netherlands report very low numbers of high-paid within-industry polarization in manufacturing. Consequently, our estimates predict around 2 times as much high-paid employment polarization within manufacturing industries than effectively observed. Therefore, these countries were also discarded. We address the issue of heterogeneity across countries later in this section.
} 
employment polarization in manufacturing, while Chinese net import competition accounts for the other 4 percent. Hence, high-paid employment polarization has been predominantly driven by ICT adoption.

Figure 4: Fraction of country-level high-paid employment polarization within manufacturing explained by ICT and Chinese net import competition (1998-2007)

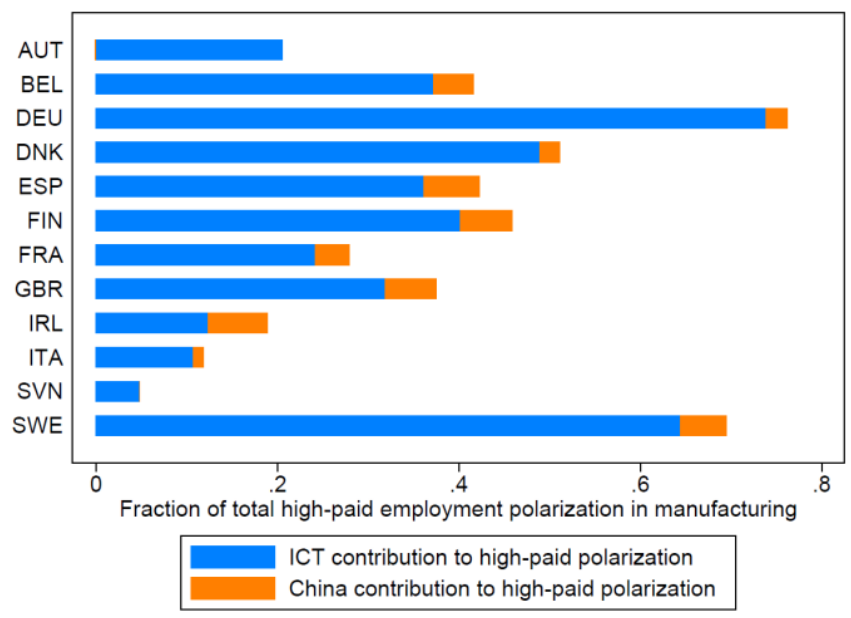

Next, we turn our attention to the other subsample of non-manufacturing private sectors in our data ${ }^{21}$. The results for this subsample are reported in table 6 . We proceed as before and first estimate a regression equation showing simple correlations before controlling for a country specific time trend. Our results in columns (1) and (2) indicate that the GVC involvement of an industry is correlated with a rise in low-paid employment polarization. However, the results suggest that offshoring is not linked with a rise in high-paid employment polarization that again points towards an asymmetric relation between the three forces and low-paid and high-paid employment polarization. We also find that a rise in the ICT intensity of an industry leads to a rise in both high-paid and low-paid employment polarization. There is no statistical association between Chinese import competition and low-paid employment polarization, likely because the non-manufacturing industries are less exposed to Chinese import competition. However, note here that non-manufacturing industries could be indirectly affected by Chinese import competition through their industrial links with manufacturing industries (Acemoglu et al., 2016). We explore this possibility in a robustness check ${ }^{22}$. In columns (3) and (4) we include a more conservative estimation strategy with countryxyear fixed effects. We find that all significance is lost.

${ }^{21}$ The private sectors included in the sample are the NACE rev. 1.1 one digit sectors electricity, gas and water supply; construction; wholesale and retail trade; hotels and restaurants; transport, storage and communication; financial intermediation; real estate, renting and business activities. We thus exclude agriculture and mining from the analysis.

${ }^{22}$ Similarly, technological shocks could equally reverberate from manufacturing to non-manufacturing industries, although we do not examine this possibility any further here. 
Table 6: Explaining within-industry polarization using broad sector non-manufacturing data (NACE one digit)

\begin{tabular}{|c|c|c|c|c|}
\hline & $\begin{array}{l}\text { (1) } \\
\text { top }\end{array}$ & $\begin{array}{c}(2) \\
\text { bottom }\end{array}$ & $\begin{array}{l}\text { (3) } \\
\text { top }\end{array}$ & $\begin{array}{c}\text { (4) } \\
\text { bottom }\end{array}$ \\
\hline OFFSH & $\begin{array}{c}0.256 \\
(0.156)\end{array}$ & $\begin{array}{c}0.286^{* *} \\
(0.105)\end{array}$ & $\begin{array}{l}0.011 \\
(0.197)\end{array}$ & $\begin{array}{c}0.308 \\
(0.253)\end{array}$ \\
\hline R\&D intensity & $\begin{array}{r}-0.008 \\
(0.014)\end{array}$ & $\begin{array}{l}-0.021^{*} \\
(0.011)\end{array}$ & $\begin{array}{l}-0.007 \\
(0.009)\end{array}$ & $\begin{array}{l}0.014 \\
(0.012)\end{array}$ \\
\hline ICT & $\begin{array}{c}0.185^{* * *} \\
(0.032)\end{array}$ & $\begin{array}{l}0.133^{* * *} \\
(0.038)\end{array}$ & $\begin{array}{l}-0.049 \\
(0.105)\end{array}$ & $\begin{array}{l}0.008 \\
(0.127)\end{array}$ \\
\hline Net Imp.pen ${ }^{C H N}$ & $\begin{array}{c}0.040 \\
(0.048)\end{array}$ & $\begin{array}{l}0.070 \\
(0.043)\end{array}$ & $\begin{array}{l}-0.016 \\
(0.05)\end{array}$ & $\begin{array}{c}0.084 \\
(0.063)\end{array}$ \\
\hline Union Density & $\begin{array}{l}-0.439 \\
(0.952)\end{array}$ & $\begin{array}{c}0.977 \\
(0.648)\end{array}$ & & \\
\hline EPL & $\begin{array}{c}0.047 \\
(0.048)\end{array}$ & $\begin{array}{c}0.043 \\
(0.029)\end{array}$ & & \\
\hline Adjusted Kaitz Index & $\begin{array}{c}0.092 \\
(0.156)\end{array}$ & $\begin{array}{c}0.196 \\
(0.160)\end{array}$ & & \\
\hline Constant & $\begin{array}{l}-1.214 \\
(0.745)\end{array}$ & $\begin{array}{l}-2.205^{\text {*** }} \\
(0.432)\end{array}$ & $\begin{array}{l}-0.492 \\
(0.606)\end{array}$ & $\begin{array}{l}-1.605^{* *} \\
(0.710)\end{array}$ \\
\hline Observations & 892 & 892 & 919 & 919 \\
\hline Industry $\times$ Country FEs & Yes & Yes & Yes & Yes \\
\hline CountryxYear FEs & No & No & Yes & Yes \\
\hline$R^{2}$ & 0.977 & 0.985 & 0.989 & 0.989 \\
\hline
\end{tabular}

Estimates based on non-manufacturing private sectors (NACE one digit) excluding agriculture and mining industries. Standard errors clustered at the country level. All variables are expressed in logs with the exception of the adjusted Kaitz index and labor union density. Observations are weighted. The dependent variable top is the ratio of high-paid employees over mid-paid employees. The dependent variable bottom is the ratio of low-paid employees over mid-paid employees.

The results in tables 5 and 6 show the merit of splitting our sample into a manufacturing and non-manufacturing subsample. The manufacturing industries have experienced a distinct type of exposure to the different technological and globalization forces compared to non-manufacturing industries. Chinese import competition and process innovation through changes in ICT and R\&D intensity were associated with within-industry polarization in manufacturing industries. In the case of ICT induced technological change and Chinese net import competition we can state with a sufficient degree of certainty that these relations are causal, while this is less clear for the other factors. Given the diverse nature of industries included in the group of non-manufacturing industries, it is likely that the exposure to globalization and the adoption of new technology could still have had idiosyncratic effects on certain industries in this group. However, we lack sufficient detail to explore this issue at depth.

In table 7 we relax the assumption that the effects that globalization and technological change have, are of common nature and size across all countries in our sample. Differences in industrial structure, favorable economic headwinds through further integration with the rest of the European economy and institutional differences across countries may have meant that the employment polarization, though common across all economies, might be differently associated with offshoring, import competition and technology depending on the group of countries one is analyzing. Indeed, Figure 3 showed substantial divergence across countries in the level of within-industry polarization for both high- and low-paid employment polarization. Therefore, we construct several country group 
dummies for Scandinavian and Anglo-Saxon countries, Central-European countries and Southern-European countries and interact these with the different globalization and technology indicators. As a reference group we use the Western-European economies so that the interaction of the geographical dummy with the different globalization and technology indicators reflects the difference in effect for that country group relative to Western-European economies. As we have thus far not found proof that labor market institutions were truly relevant in affecting withinindustry polarization, we have dropped these measures from our specification.

Our findings confirm our previous conclusion that ICT induced technological change is associated with high-paid employment polarization in manufacturing industries. Moreover, in manufacturing industries there is some evidence that the size of the effect differs across country groups. In Central- and Southern-European countries the correlation between ICT intensity and high-paying employment polarization is often weaker, although this difference is not robust to the inclusion of a country-specific time trend. In the case of R\&D the outcome appears to be particularly sensitive to the inclusion of a time trend raising doubts on the robustness of this measure of process innovation. We will therefore present robustness checks later on to explore this type of process innovation using an alternative definition of process innovation. Interestingly, when accounting for geographical differences we find that Chinese net import competition now switches its impact from high- to low-paid employment polarization. Furthermore, Chinese competition has contributed to increased low-paid within-industry employment polarization in all advanced country groups except in Central and Southern European countries. The same geographical pattern was found also for the impact of ICT- and R\&D-induced technological change. This is consistent with Figure 3 showing that lowpaid within-industry employment polarization in all Central and Southern European countries actually decreased over the period 1997-2007. This implies that in this period the middle-paid employment shares in these two country groups were strengthened. One explanation for this is increased manufacturing FDI flows to Central and Southern European countries in this period seeking lower labor cost of routine jobs. In other words, the potential trends of increased lowpaid employment polarization in Central and Southern European countries might have been offset by the inflow of FDI into manufacturing industries. It thus seems that increased either low- or high-paying (or both) within-industry employment polarization in manufacturing sectors of Western countries can be largely explained by the impact of technology (R\&D- and ICT-induced) and globalization (Chinese competition), but less so in other European regions.

In non-manufacturing sectors we find some evidence on the impact of technology (but only ICT-induced) and China-driven globalization on increased within-industry employment polarization in low-paying jobs, whereby these effects are significantly lower in Central and Southern European countries. These effects largely disappear when controlling for countryxyear fixed effects.

In addition, in an attempt to explain how the same shocks can have different effects on within-industry polarization, table $\mathrm{B} 1$ and $\mathrm{B} 2$ of appendix $\mathrm{B}$ analyze how interactions of the labor market institutions and globalization and technological change are related to polarization. There is some indication that in countries with strong institutions Chinese net import competition led to more high-paying employment polarization in manufacturing industries, while offshoring led to more low-paying employment polarization. The results in table B1 would suggest this is mostly driven by Union density. However, the strongly institutionalized countries are less sensitive to the effects of ICT induced technological change on low-employment polarization. This could explain why three of the countries (Belgium, Italy and Slovenia) that according to our definition are highly institutionalized incurred strong within-industry high-paying employment polarization combined with a decline in low-paying employment. However, other countries with weaker institutions have shown similar trends making the role of labor market institutions less clear. It is more likely that the varying nature of the results in table B1 and B2 point towards other underlying factors that are determining how sensitive industries are to within-industry polarization. Hence, industries in different countries seem to show differing degrees of sensitivity to globalization and technological forces independent of the type of labor market institutions these countries have. 
Table 7: Explaining within-industry polarization in manufacturing and non-manufacturing sectors in the period 1996 - 2007 : Differences across country groups

\begin{tabular}{|c|c|c|c|c|c|c|c|c|}
\hline & \multicolumn{4}{|c|}{ Manufacturing } & \multicolumn{4}{|c|}{ Non-manufacturing } \\
\hline & (1) & (2) & (3) & (4) & (5) & (6) & (7) & (8) \\
\hline & Top & Bottom & Top & Bottom & Top & Bottom & Top & Bottom \\
\hline OFFSH & 0.258 & 0.317 & $-0.288 * *$ & -0.372 & 0.021 & 0.088 & -0.332 & 0.052 \\
\hline OFFSH*Scand.\&A-Saxon & 0.062 & -0.413 & 0.277 & 0.242 & 0.259 & -0.260 & 0.568 & 0.226 \\
\hline OFFSH $*$ Central Europe & 0.487 & -0.746 & $0.676^{*}$ & 0.541 & -0.553 & 0.107 & -0.203 & 0.322 \\
\hline OFFSH*Southern Europe & 0.493 & 0.228 & 0.097 & 0.812 & 0.632 & 0.326 & 0.628 & 0.495 \\
\hline R\&D intensity & $0.085^{* *}$ & $0.289 * * *$ & $-0.062 *$ & -0.014 & 0.028 & -0.022 & 0.002 & -0.011 \\
\hline R\&D*Scand.\&A-Saxon & -0.008 & $-0.327 * *$ & 0.108 & -0.026 & -0.040 & 0.026 & -0.017 & $0.046^{*}$ \\
\hline R\&D*Central Europe & -0.022 & $-0.264 * *$ & $0.102 *$ & -0.007 & -0.041 & 0.022 & -0.012 & 0.011 \\
\hline R\&D*Southern Europe & 0.069 & $-0.204^{* *}$ & $0.164 * * *$ & 0.078 & -0.026 & $0.051^{* *}$ & 0.004 & 0.040 \\
\hline ICT & $0.321 * * *$ & 0.278 & $0.199 * * *$ & 0.071 & $0.243^{* * * *}$ & $0.125 * * *$ & -0.126 & -0.074 \\
\hline ICT*Scand.\&A-Saxon & -0.096 & -0.125 & -0.089 & -0.111 & -0.007 & $0.163^{* *}$ & 0.149 & 0.332 \\
\hline ICT*Central Europe & $-0.267 * *$ & $-0.646^{*}$ & -0.170 & -0.152 & -0.087 & $-0.139 * * *$ & 0.115 & $0.504 * * *$ \\
\hline ICT*Southern Europe & -0.148 & $-0.444 * *$ & -0.034 & 0.024 & $-0.162^{*}$ & $-0.240^{* *}$ & 0.064 & -0.093 \\
\hline Imp.pen ${ }^{C H N}$ & 0.013 & $0.016^{* *}$ & 0.011 & 0.018 & 0.121 & $0.158^{* * * *}$ & -0.047 & 0.142 \\
\hline Imp.pen ${ }^{C H N *}$ Scand.\&A-Saxon & 0.021 & 0.048 & 0.012 & 0.023 & -0.062 & -0.033 & 0.103 & 0.004 \\
\hline Imp.pen ${ }^{C H N *}$ Central Europe & -0.018 & $-0.046^{* *}$ & $-0.015^{*}$ & $-0.037 * *$ & $-0.216 * *$ & -0.290 & -0.093 & -0.211 \\
\hline Imp.pen ${ }^{C H N *}$ Southern Europe & 0.010 & $-0.024 * * *$ & 0.010 & -0.006 & $-0.210 * *$ & $-0.156^{* * * *}$ & -0.077 & -0.146 \\
\hline Constant & $-2.756^{* * * *}$ & $-2.405^{* * *}$ & $-0.921 * *$ & $-1.797 * *$ & $-0.925 * *$ & $-1.144 * * *$ & -0.173 & $-1.77 * * *$ \\
\hline$N$ & 2053 & 2048 & 2053 & 2048 & 919 & 919 & 919 & 919 \\
\hline Industry $\times$ country FEs & Yes & Yes & Yes & Yes & Yes & Yes & Yes & Yes \\
\hline Country $\times$ Year FEs & No & No & Yes & Yes & No & No & Yes & Yes \\
\hline$R^{2}$ & 0.932 & 0.819 & 0.955 & 0.906 & 0.977 & 0.986 & 0.989 & 0.989 \\
\hline
\end{tabular}

Estimates based on manufacturing (NACE two digit) sectors in columns (1) to (4) and non-manufacturing (NACE one digit) sectors excluding agriculture and mining in columns (5) to (8). Standard errors clustered at the country level. Observations are weighted. Countries in our sample are divided into four different geographic groups: Scandinavian and AngloSaxon countries (Denmark, Finland, Norway, Sweden, United Kingdom and Ireland), core Western-European countries (Austria, Belgium, France, Germany and Netherlands),

Southern-European countries (Spain and Italy) and Central-European countries (Czech Republic, Hungary and Slovenia). 
We now discuss several robustness checks that we have performed and which we present in appendix B. From table 7 it has emerged that R\&D intensity is particularly sensitive to the chosen specification and the effects are not robust to the inclusion of a reasonable time trend. A possible comment to the use of R\&D intensity as an indicator of technological change is that it measures technology input and therefore does not necessarily capture technological output and, hence, technological change. We perform a robustness check to test a specification using a variable that also reflects process innovation but that is more closely related to technological output. In particular, we use the number of patents per employee in the industry collected from EUROSTAT as a proxy for technological change. Given the limited relevance of $R \& D$ to non-manufacturing industries, we limit our robustness check to manufacturing industries. Table B3 reports the results. While the sign of the patent variable shows a positive statistical relation between technological change and high-paid within-industry polarization in manufacturing, it is never close to significance. ICT remains robustly estimated for high-paid employment polarization.

We have used net import competition to look at the net impact of the emergence of China on withinindustry polarization. In table B4 we split net import penetration in an import and an export term and analyze its effects on manufacturing within-industry polarization. The results indicate that import competition increased polarization within an industry, while new export opportunities offset this effect. However, both variables are not significant at the conventional levels. Next, we turn to the nonmanufacturing industries. The non-tradable nature of the output of several non-manufacturing industries and the limited increase in Chinese services imports have meant that non-manufacturing EU industries have generally not faced direct Chinese import competition. However, several of these industries are indirectly exposed to a Chinese import penetration shock as they provide services that are used as an input by the manufacturing industries. Hence, the demise of manufacturing industries at the hands of manufacturing imports from China leaves non-manufacturing industries exposed through their industrial links with manufacturing industries (Acemoglu et al., 2016; Acemoglu et al., 2015). The construction of our downstream exposure measure is discussed in appendix B. The industrial links between the industries are derived from the WIOD I/O-tables (Timmer et al., 2015). In table B5 we show that even when we account for these downstream links we do not find that Chinese net import competition affected withinindustry polarization in non-manufacturing industries.

\subsection{Between-industry polarization}

\subsubsection{Empirical framework}

Section 2.2. showed that a substantial fraction of overall polarization is accounted for by the reallocation of employment between industries within the broader economy. To understand the role of GVCs, import competition and technology in overall polarization, we require an additional specification that relates changes in the employment of industries in the economy to these factors. The empirical approach of Acemoglu et al. (2016) offers a useful framework that analyzes the effect of Chinese import competition on employment. We compute the change in GVC participation (as a proxy for offshoring), import competition of China and R\&D intensity over one long pre-crisis period and over a smaller postcrisis period ${ }^{23}$. Subsequently, we perform the analysis using two separate specifications: one where we exclusively consider the long pre-crisis period and one where we consider both the pre- and the post-

\footnotetext{
${ }^{23}$ The structural break in the data in 2008 caused by a change in the NACE industry classification is circumvented by choosing a pre-crisis sample with NACE 1.1 industry classification and a post-crisis sample with NACE 2 industry classification.
} 
crisis periods. The specification where we exclusively use the long pre-crisis period is of the following form $^{24}$ :

$$
\begin{gathered}
\Delta \ln E m p_{i c t}=\gamma_{1}+\gamma_{2} \Delta O F F S H_{i c t}+\gamma_{3} \Delta R \& D \text { Intensity } y_{i c t}+\gamma_{4} \Delta \ln I C T_{i c t}+\gamma_{5} \Delta \mathrm{Net} I m p . p e n_{i c t}^{C H N}+ \\
\delta_{c}+\omega_{i c t}
\end{gathered}
$$

$\Delta \ln E m p_{i c t}$ is 100 times the log change in the employment of an industry. $\delta_{c}$ is a country fixed effect included to control for a general country employment trend. By controlling for the country fixed effects we concentrate on growth differentials between industries within the countries. We replace the country fixed effect with a country $\times$ period fixed effect, $\delta_{c t}$, when considering both the pre- and the post-crisis period so we control for the country-specific severity of the crisis. Since we have no data on ICT after 2007, this indicator of technological change was excluded from any analysis that included the crisis period. Each observation is weighted with the beginning of period employment share in national employment. In equation (4) we multiplied $\Delta$ Net Imp.pen by 100 for ease of interpretation of our regression output. We now do the same for $\triangle R \& D$ Intensity and $\triangle O F F S H$ so that these represent 100 times the level changes in the R\&D Intensity of the industry and the offshoring ratio, respectively. $\Delta \ln I C T$ is 100 times the log changes in ICT usage in the industry.

While the above equation will show how employment was affected by the different shocks that have hit the labor market, it is not directly linked with polarization. Therefore, we also present results of a specification where we interact all the independent variables with an indicator that is equal to one when a specific industry is above or below the median level of polarization in 1998. Reallocation could then have occurred if initially lowly polarized industries were harder hit by the different shocks, while initially highly polarized industries were left largely unaffected by the shocks.

Our estimates might be subject to concerns of endogeneity as reported by Autor et al. (2013) and Acemoglu et al. (2016). This issue could be particularly severe in our specification since our sample includes several countries. If the country and the countryxtime fixed effects are unable to properly control for local demand effects, the Chinese import competition coefficient will be upwardly biased since a demand boom will raise both employment and imports in some sectors. Given that there are several countries in our sample which have undergone such demand-driven booms, the issue is likely pervasive. Therefore, we limit our between-industry analysis to basic specifications and leave a more rigorous approach to future research.

\subsubsection{Results}

We first look at the results for manufacturing industries in table 8 and then analyze the same specification for non-manufacturing industries.

\footnotetext{
${ }^{24}$ In terms of equation 1 we explain the changes in the employment shares, $\Delta S_{i, c}$, by investigating the relationship between the different explanatory factors and industry employment, $E_{i c t}$.
} 
Table 8: Explaining employment growth in manufacturing industries in the period 1998 - 2010

\begin{tabular}{|c|c|c|c|c|}
\hline & (1) & (2) & (3) & (4) \\
\hline$\triangle O F F S H$ & $\begin{array}{c}0.648 \\
(1.017)\end{array}$ & $\begin{array}{c}0.236 \\
(0.683)\end{array}$ & $\begin{array}{c}-0.807 \\
(0.516)\end{array}$ & $\begin{array}{l}-0.778 \\
(0.708)\end{array}$ \\
\hline$\Delta R \& D$ Intensity & $\begin{array}{c}0.224 \\
(1.337)\end{array}$ & $\begin{array}{l}-0.661 \\
(1.066)\end{array}$ & $\begin{array}{c}0.784 \\
(2.221)\end{array}$ & $\begin{array}{l}-0.695 \\
(3.036)\end{array}$ \\
\hline$\Delta \ln I C T$ & $\begin{array}{l}-0.057 \\
(0.076)\end{array}$ & & $\begin{array}{l}-0.030 \\
(0.091)\end{array}$ & \\
\hline$\Delta N e t$ Imp.pen ${ }^{C H N}$ & $\begin{array}{c}-3.156^{* * * *} \\
(1.029)\end{array}$ & $\begin{array}{c}-2.413 * * * \\
(0.623)\end{array}$ & $\begin{array}{c}-6.441^{* * *} \\
(1.000)\end{array}$ & $\begin{array}{c}-5.912 * * * \\
(0.818)\end{array}$ \\
\hline$\triangle O F F S H$ xhighly polarized & & & $\begin{array}{c}2.597 * * \\
(0.655)\end{array}$ & $\begin{array}{l}1.646^{* *} \\
(0.702)\end{array}$ \\
\hline$\Delta R \& D$ Intensity $\times$ highly polarized & & & $\begin{array}{l}-2.816 \\
(2.282)\end{array}$ & $\begin{array}{l}-1.255 \\
(3.259)\end{array}$ \\
\hline$\Delta \ln I C T \times$ highly polarized & & & $\begin{array}{c}0.114 \\
(0.071)\end{array}$ & \\
\hline$\Delta$ Net Imp. pen ${ }^{C H N} \times$ highly polarized & & & $\begin{array}{l}7.18^{* * * *} \\
(1.505)\end{array}$ & $\begin{array}{c}6.809 * * * \\
(1.289)\end{array}$ \\
\hline Highly polarized & & & $\begin{array}{c}-17.246^{*} \\
(9.013)\end{array}$ & $\begin{array}{l}-6.783 * \\
(3.344)\end{array}$ \\
\hline Constant & $\begin{array}{c}2.179 \\
(8.984)\end{array}$ & $\begin{array}{c}-2.647 * * * \\
(2.890)\end{array}$ & $\begin{array}{c}4.760 * \\
(11.412)\end{array}$ & $\begin{array}{l}7.641 * * \\
(3.138)\end{array}$ \\
\hline $\mathrm{N}$ & 139 & 345 & 139 & 345 \\
\hline Country FEs & Yes & No & Yes & No \\
\hline Country $\times$ period FEs & No & Yes & No & Yes \\
\hline$R^{2}$ & 0.36 & 0.25 & 0.58 & 0.39 \\
\hline
\end{tabular}

\footnotetext{
Estimates based on manufacturing (NACE two-digit) sectors. Standard errors clustered at the country level. $\triangle O F F S H, \triangle R \& D$ Intensity, $\Delta \ln I C T$ and $\triangle N e t$ Imp. pen ${ }^{C H N}$ have all been multiplied by 100 to facilitate the interpretation. Observations are weighted by beginning of period employment share in national employment. The dependent variable is 100 times the change in the log of employment. Petroleum and nuclear fuel industry is excluded from the analysis. Highly Polarized is a dummy equal to one when the initial polarization rate of the industry is above the median polarization rate observed across all manufacturing industries in the relevant country. Column (1), (3) and (5): Long differences from 1998 to 2007.

Column (2), (4) and (6): Stacked differences from 1998 to 2007 and 2008 to 2010.

Robust standard errors in parentheses. $* * * \mathrm{p}<0.01, * * \mathrm{p}<0.05, * \mathrm{p}<0.1$
}

The results in columns (1) and (2) show that only Chinese import penetration is significantly correlated with employment growth by sectors, while offshoring and technology do not seem to contribute to employment changes. Specifically, a change in the net Chinese import penetration ratio by one percentage point is significantly correlated with a decrease of employment in manufacturing industries by 2.41 to 3.16 percent. To gauge the economic significance of these results, we use the estimates in column (2) and compute the estimated employment decline that took place in manufacturing for each individual country from 1998 to 2010. When we weight these employment declines according to the initial employment share, we find that 21 percent of the total decline in manufacturing employment in Europe has resulted from Chinese net import competition. This implies a loss of 944,000 employees in manufacturing across the EU. Acemoglu et al. (2016) find that in the U.S. the direct impact of Chinese import competition amounted to around 10 percent of the observed employment decline in manufacturing. Hence, this shows how Chinese net import competition has induced employment declines in relatively lowly polarized manufacturing industries across Europe. Interestingly, when interacting our main explanatory variables with the degree of initial sector's labor polarization, the results in columns (3) and (4) show that initially highly polarized industries were less sensitive to the Chinese net import penetration shock. The same is true for offshoring. Conversely, industries that were polarized below the median 
polarization rate of manufacturing industries in a country were more severely affected by the Chinese net import penetration shock and offshoring. However, this effect is offset by the fact that simply being initially highly polarized is linked with employment decline in those industries ${ }^{25}$.

Our decomposition has shown that polarization is mostly a result of the reallocation of labor away from manufacturing industries towards service industries rather than the reallocation of labor between manufacturing industries. Therefore, it is particularly important to analyze whether highly polarized non-manufacturing industries have experienced employment increases.

We therefore move on to results for the non-manufacturing industries (Table 9). In column (1) there is some evidence that $R \& D$ induced technological change led to an increase in employment. However, this finding is not robust across all specifications. In columns (5) and (6) we account for the indirect exposure of nonmanufacturing industries to the Chinese net import penetration shock that affected manufacturing industries. Acemoglu et al. (2016) showed that this indirect shock that occurred downstream in the production chain affected employment in these industries. In column (6) we find evidence corroborating this finding. Specifically, our results indicate that a net import penetration shock of one percentage point in all downstream manufacturing industries leads to an employment decline of 26.54 percent in the non-manufacturing industries. Meanwhile, the effect was non-existent in highly polarized non-manufacturing industries. As this estimate is four times larger than the one found by Acemoglu et al. (2016) for U.S. industries and is only significant when the crisis period is included, caution is clearly warranted as there is an endogeneity bias affecting the estimates. Hence, we only consider this as tentative evidence. We also find that initially highly polarized nonmanufacturing industries in European countries saw employment increases in line with what one would expect given the reallocation of labor towards more polarizing industries. Again, this coefficient is only significant when we include the crisis period, so this can only be considered as circumstantial evidence.

${ }^{25}$ In a separate analysis (not reported here) we decompose the net import penetration shock into an export and an import component. As expected, export penetration to China increased industry employment while import penetration decreased it. Remarkably, depending on the specification export penetration had a coefficient up to four times as large as the one on import penetration. As on average import competition shocks were around double the size of export penetration shocks, this will have meant that in several industries across the EU new export opportunities to China will have been able to offset the negative effects of import competition. 
Table 9: Explaining employment growth in broad non-manufacturing sectors in the period 1998 - 2010

\begin{tabular}{|c|c|c|c|c|c|c|}
\hline & (1) & (2) & (3) & (4) & (5) & (6) \\
\hline$\triangle O F F S H$ & $\begin{array}{c}-0.790 \\
(1.508)\end{array}$ & $\begin{array}{l}-2.819^{*} \\
(1.378)\end{array}$ & $\begin{array}{c}-0.772 \\
(1.547)\end{array}$ & $\begin{array}{l}-2.346 \\
(1.663)\end{array}$ & $\begin{array}{l}-0.684 \\
(1.449)\end{array}$ & $\begin{array}{l}-1.828 \\
(1.546)\end{array}$ \\
\hline$\Delta R \& D$ Intensity & $\begin{array}{c}36.061 * * \\
(14.29)\end{array}$ & $\begin{array}{c}10.674 \\
(13.208)\end{array}$ & $\begin{array}{c}31.069 \\
(26.107)\end{array}$ & $\begin{array}{c}25.439 \\
(17.803)\end{array}$ & $\begin{array}{c}26.509 \\
(24.831)\end{array}$ & $\begin{array}{c}23.592 \\
(17.873)\end{array}$ \\
\hline$\Delta \ln I C T$ & $\begin{array}{c}0.156 \\
(0.104)\end{array}$ & & $\begin{array}{c}0.140 \\
(0.105)\end{array}$ & & $\begin{array}{c}0.144 \\
(0.129)\end{array}$ & \\
\hline$\Delta N e t$ Imp.pen ${ }^{C H N}$ & $\begin{array}{l}-2.211 \\
(9.575)\end{array}$ & $\begin{array}{c}1.048 \\
(1.846)\end{array}$ & $\begin{array}{c}9.700 \\
(10.650)\end{array}$ & $\begin{array}{c}0.555 \\
(2.875)\end{array}$ & $\begin{array}{c}14.705 \\
(13.134)\end{array}$ & $\begin{array}{c}1.975 \\
(3.528)\end{array}$ \\
\hline$\Delta$ Indirect Net Imp. pen ${ }^{\mathrm{CHN}}$ & & & & & $\begin{array}{l}-30.625 \\
(32.078)\end{array}$ & $\begin{array}{l}-26.541^{*} \\
(13.084)\end{array}$ \\
\hline$\triangle O F F S H$ xhighly polarized & & & $\begin{array}{l}-1.747 \\
(2.269)\end{array}$ & $\begin{array}{l}-1.020 \\
(1.510)\end{array}$ & $\begin{array}{l}-1.290 \\
(2.419)\end{array}$ & $\begin{array}{l}-1.365 \\
(1.405)\end{array}$ \\
\hline$\Delta R \& D$ Intensity $\times$ highly polarized & & & $\begin{array}{l}-3.706 \\
(28.820)\end{array}$ & $\begin{array}{l}-25.794 \\
(19.045)\end{array}$ & $\begin{array}{c}1.564 \\
(27.935)\end{array}$ & $\begin{array}{l}-23.038 \\
(19.109)\end{array}$ \\
\hline$\Delta \ln I C T \times$ highly polarized & & & $\begin{array}{c}-0.118 \\
(0.270)\end{array}$ & & $\begin{array}{l}-0.109 \\
(0.289)\end{array}$ & \\
\hline$\Delta$ Net Imp.pen ${ }^{C H N} \times$ highly polarized & & & & & $\begin{array}{l}-33.282 \\
(30.020)\end{array}$ & $\begin{array}{c}0.088 \\
(3.210)\end{array}$ \\
\hline $\begin{array}{l}\Delta \text { Ind. Net Imp. pen }{ }^{C H N} \times \text { highly } \\
\text { polarized }\end{array}$ & & & $\begin{array}{l}-28.732 \\
(25.495)\end{array}$ & $\begin{array}{c}0.830 \\
(2.669)\end{array}$ & $\begin{array}{c}36.339 \\
(30.660)\end{array}$ & $\begin{array}{c}24.897 * * * \\
(10.016)\end{array}$ \\
\hline Highly polarized & & & $\begin{array}{c}26.033 \\
(30.508)\end{array}$ & $\begin{array}{c}15.272 * * * \\
(4.032)\end{array}$ & $\begin{array}{c}18.290 \\
(35.882)\end{array}$ & $\begin{array}{c}14.501 * * * \\
(4.189)\end{array}$ \\
\hline Constant & $\begin{array}{l}-15.664 \\
(13.170)\end{array}$ & $\begin{array}{c}68.770 * * * \\
(19.246)\end{array}$ & $\begin{array}{l}-15.098 \\
(11.022)\end{array}$ & $\begin{array}{c}84.471 \text { *** } \\
(27.550)\end{array}$ & $\begin{array}{l}-14.738 \\
(9.723)\end{array}$ & $\begin{array}{c}88.408 \\
(26.329)\end{array}$ \\
\hline $\mathrm{N}$ & 59 & 146 & 59 & 146 & 59 & 146 \\
\hline Country FEs & Yes & No & Yes & No & Yes & No \\
\hline Country $\times$ period FEs & No & Yes & No & Yes & No & Yes \\
\hline$R^{2}$ & 0.49 & 0.44 & 0.55 & 0.58 & 0.56 & 0.60 \\
\hline
\end{tabular}

Notes: Estimates based on non-manufacturing (NACE one-digit) sectors. Standard errors clustered at the country level. $\triangle O F F S H, \triangle R \& D$ Intensity, $\Delta \ln I C T$ and $\Delta N e t I m p . p e n^{C H N}$ have all been multiplied by 100 to facilitate the interpretation. Observations are weighted by beginning of period employment share in national employment. The dependent variable is the change in the log of employment. Highly Polarized is a dummy equal to one when the initial polarization rate of the industry is above the median polarization rate observed across all nonmanufacturing industries in the relevant country.

Column (1), (3) and (5): Long differences from 1998 to 2007.

Column (2), (4) and (6): Stacked differences from 1998 to 2007 and 2008 to 2010.

Robust standard errors in parentheses. *** $\mathrm{p}<0.01, * * \mathrm{p}<0.05, * \mathrm{p}<0.1$

\subsection{Discussion}

A recent spate of studies exploring polarization using firm-level data have found evidence of ICT or technology adoption leading to increased polarization (Harrigan et al., 2016; Heyman, 2016; Kerr et al., 2016; Böckerman et al., 2016). Our analysis shows that the conclusions of these firm-level studies also emerge in a more aggregated sample and are not limited to a limited number of countries but are more general across different countries. Our results suggest that ICT adoption was the predominant driving factor behind the relative increase of high-paid employment in manufacturing industries. This is consistent with theoretical models, such as Acemoglu and Autor (2011) and others, where the trigger is labor augmenting technological 
progress benefiting the high-skilled tasks, at the expense of middle-skilled tasks. During the time period we consider in our analysis, we witness strong changes in ICT capital services per hour worked. In both manufacturing and non-manufacturing industries ICT capital services have doubled over the time period of our analysis.

Our results also underline the relevance of Chinese import competition in aggregate polarization. Again, our results are in line with micro-evidence in the literature. Keller and Utar (2016) use Danish employeremployee matched data and find that Chinese import competition explained about a fifth of the overall midwage employment decline. Moreover, they also found that Chinese import competition induced restructuring of employment away from manufacturing towards low-wage services. We find some evidence that Chinese net import competition induced high-paying employment polarization within manufacturing industries. However, our results show that Chinese import competition did not affect within-industry polarization in all countries equally, but affected only core Western, Scandinavian \& Anglo-Saxon EU countries. Chinese import competition was particularly relevant in explaining employment shifts towards more polarized industries. We find tentative evidence that non-manufacturing industries that supply manufacturing industries facing Chinese import competition suffered stronger employment declines when the industry was initially less polarized. This evidence suggests that aside from the general impact Chinese import competition had on employment (Acemoglu et al., 2016; Autor et al., 2013, Balsvik, 2013; Dauth et al., 2014; Donoso et al., 2014), the role it played in restructuring employment in the labor market also increased aggregate polarization. Our analysis thus suggests that while ICT adoption and Chinese import competition both contributed to aggregate polarization, they did so in diverse ways.

We find that there is considerable heterogeneity in the level of polarization across the different countries. Moreover, the way in which polarization has manifested itself across countries, with varying degrees of withinindustry polarization and employment reallocation between industries, makes it important to find out what is driving these diverse patterns. While labor market institutions differ considerably within the panel of countries we consider, we have not found outspoken evidence that these institutions affected polarization. One likely explanation is that other underlying country-specific shocks might have aggravated the already existing pattern of polarization and induced the cross-country heterogeneity in polarization patterns that we observe. For instance, Nickell et al. (2008) noted that the different pace of deindustrialization across (OECD) countries, which we have found to be tied to the phenomenon of employment polarization, can be explained by differential changes in relative prices of manufacturing and non-manufacturing goods and productivity growth. Hence, such factors will have contributed both directly and indirectly in generating the cross-country heterogeneity in polarization. 


\section{Conclusion}

This paper has examined how employment polarization is associated with the forces of technological change, offshoring and import competition in European economies. We show that aggregate polarization is a result of high and low paying employment increasing within individual industries as well as the reallocation of labor away from industries with low polarization such as manufacturing towards industries with relatively high polarization such as the service industries. We find that both aspects of polarization were affected differently by technological change and globalization.

ICT adoption explains around a third of high paying employment polarization within individual manufacturing industries, while Chinese net import competition also contributed to this phenomenon but only explains a very small fraction. Low-paying employment polarization within industries varied greatly across countries and our results do not indicate that there is a clear link between this type of polarization and the globalization and technology shocks. To understand the polarization that has occurred as a result of the reallocation of employment from less polarized to more polarized industries, we have analyzed the relation between globalization and technological change, on the one hand, and employment growth in the industries. We found that Chinese net import penetration accounts for about a fifth of employment losses in lowly polarized manufacturing industries. However, we find no proof that technological change played any role in this reallocation of labor.

This paper offers several interesting pathways for future research and some policy prescriptions. First, we have demonstrated that different forces will affect labor markets in countries in distinct ways. To formulate a guideline for policy it is necessary to determine what characteristics of the labor market cause these divergent reactions. In this respect, this paper has shown that differences between countries in labor market institutions are not a sufficient explanation. However, future research will have to focus on these country-specific factors and their interaction with the drivers of polarization to be able to provide relevant policy prescriptions. The widespread nature of polarization does suggest that there is a clear necessity for the use of policy instruments to smooth the process of transition for workers. Second, we have chosen to study within- and between-industry polarization as two complementary processes. However, we have not addressed how both these processes are directly related. To understand how any outside force can lead to overall polarization, both types of polarization need to be considered in conjunction. Finally, throughout this paper we have considered the forces of technology and globalization as unrelated shocks influencing the polarization process. Nevertheless, all these factors are entangled so that a change in one factor directly affects the other. Disentangling these effects is clearly important in understanding the role of each force in polarization. 


\section{References}

Acemoglu, D. and Autor, D. (2011). Skills, Tasks and Technologies: Implications for Employment and Earnings, volume 4, chapter 12, pages 1043-1171.

Acemoglu, D., Akcigit, U., and Kerr, W. (2015). Networks and the macroeconomy: An empirical exploration. No. w21344, National Bureau of Economic Research.

Acemoglu, D., Autor, D., Dorn, D., Hanson, G., and Price, B. (2016). Import competition and the great us employment sag of the 2000s. Journal of Labor Economics, 34(1):S141-S198.

Autor, D. H., Levy, F., \& Murnane, R. J. (2003). The skill content of recent technological change: An empirical exploration. The Quarterly journal of economics, 118(4), 1279-1333.

Autor, D. (2010). The polarization of job opportunities in the us labor market: Implications for employment and earnings. Center for American Progress and the Hamilton Project.

Autor, D. and Dorn, D. (2013). The growth of low skill service jobs and the polarization of the u.s. labor market. American Economic Review, 103(5):1553-1597.

Autor, D., Dorn, D., and Hanson, G. (2013). The china syndrome: Local labor market effects of import competition in the united states. American Economic Review, 103(6):2121-2168.

Autor, D. (2015). Why are there still so many jobs. The Journal of Economic Perspectives, 29(3):3- 30.

Balsvik, R., Jensen, S., and Salvanes, K. G. (2013). Made in China, sold in Norway: Local labor market effects of an import shock. Journal of Public Economics, 127:137-144.

Böckerman, P., Laaksonen, S., Vainiomäki, J. (2016). Are Jobs More Polarized in Ict Firms? , IZA Discussion Paper

Bogliacino, F., Piva, M., and Vivarelli, M. (2012). R\&D and employment: An application of the lsdvc estimator using european microdata. Economics Letters, 116(1):56-59.

Brynjolfsson, E. and McAfee, A. (2014). The Second Machine Age: Work, Progress and Prosperity in a Time of Brilliant Technologies. WW Norton \& Company.

Dauth, W., Findeisen, S., and Suedekum, J. (2014). The rise of the east and the far east: German labor markets and trade integration. Journal of the European Economic Association, 12(6):1643- 1675.

Donoso, V., Martín, V., and Minondo, A. (2015). Do differences in the exposure to Chinese imports lead to differences in local labour market outcomes? An analysis for Spanish provinces. Regional Studies, 49(10):1746-1764.

Harrigan, J., Reshef, A., Toubal, F. (2016). The March of the Techies: Technology, Trade, and Job Polarization in France, 1994-2007. No.22110, National Bureau of Economic Research.

Heyman, F. 2016. Job Polarization, Job Tasks and the Role of Firms. Economic Letters(145), 246-251.

Goos, M., Konings, J., and Rademakers, E. (2016). Future of work in the digital age: Evidence from OECD countries.Flexibility@work2016.

Goos, M., Manning, A., and Salomons, A. (2014). Explaining job polarization: Routine-biased technological change and offshoring. American Economic Review, 104(8):2509-2526. 
Katz, L. and Margo, R. A. (2014). Human Capital in History: The American Record, chapter Technical Change and the Relative Demand for Skilled Labor: The United States in Historical Perspective, pages 15-57. National Bureau of Economic Research, Inc.

Keller, W. and Utar, H. (2016). International trade and job polarization: Evidence at the worker-level. no. w22315, National Bureau of Economic Research.

Klette, J. and Forre, S. E. (1998). Innovation and job creation small open economy-evidence from Norwegian manufacturing plants 1982-92. Economics of Innovation and New Technology, 5(24):247-272.

Manning, A. (2003). Monopsony in motion: Imperfect Competition in Labor Markets. Princeton University Press.

Mazzolari, F., \& Ragusa, G. (2013). Spillovers from high-skill consumption to low-skill labor markets. Review of Economics and Statistics, 95(1), 74-86.

Nickell, S, Redding, S., and Swaffield, J. (2008). The uneven pace of deindustrialization in the OECD. The World Economy, 31(9):1154-1184.

Kerr, S. Pekkala, Maczulskij, T., Maliranta, M. (2016). Within and between Firm Trends in Job Polarization: Role of Globalization and Technology. The Research Institute of the Finnish Economy, Working Papers No. 41.

OECD (2016). OECD.stat.

OECD and WTO (2015). Trade in value-added: Concepts, methodologies, and challenges.

Oldenski, L. (2014). Offshoring and the polarization of the U.S. labor market. Industrial and Labor Relations Review.

Timmer, M., Dietzenbacher, E., Los, B., Stehrer, R., and de Vries, G. (2015). An illustrated guide to the world input-output database: the case of global automotive production. Review of International Economics, 23:575-605.

Visser, J. (2015). ICTWSS database. version 5.0. Amsterdam Institute for Advanced Labour Studies AIAS. 


\section{A Summary statistics and graphs}

\section{A.1 Offshoring}

Table A1: Offshoring measure: Initial levels and evolution from 1995 to 2007 at the country

\begin{tabular}{lcc}
\multicolumn{3}{c}{ level } \\
\hline Country & OFFSH in 1995 & Change from 1995 to 2007 \\
\hline Ireland & 38.5 & 4.59 \\
Slovenia & 32.3 & 4.45 \\
Slovakia & 31.9 & 14.85 \\
Belgium & 31.1 & 3.74 \\
Czech Republic & 30.5 & 11.92 \\
Hungary & 30.1 & 16.83 \\
Portugal & 27.4 & 5.77 \\
Sweden & 26.3 & 4.84 \\
Finland & 24.1 & 8.92 \\
Netherlands & 23.2 & -3.99 \\
Denmark & 23.1 & 8.82 \\
Austria & 21.5 & 6.08 \\
Spain & 19.2 & 7.99 \\
Great-Britain & 18.3 & 0.47 \\
France & 17.3 & 7.04 \\
Italy & 17.2 & 7.31 \\
Greece & 16.3 & 7.71 \\
Germany & 14.9 & 8.77 \\
\hline \hline
\end{tabular}

Authors' calculations based on OECD (2016)

\section{A.2 Chinese import competition}

Figure A1: Change in Chinese import penetration 1995-2007
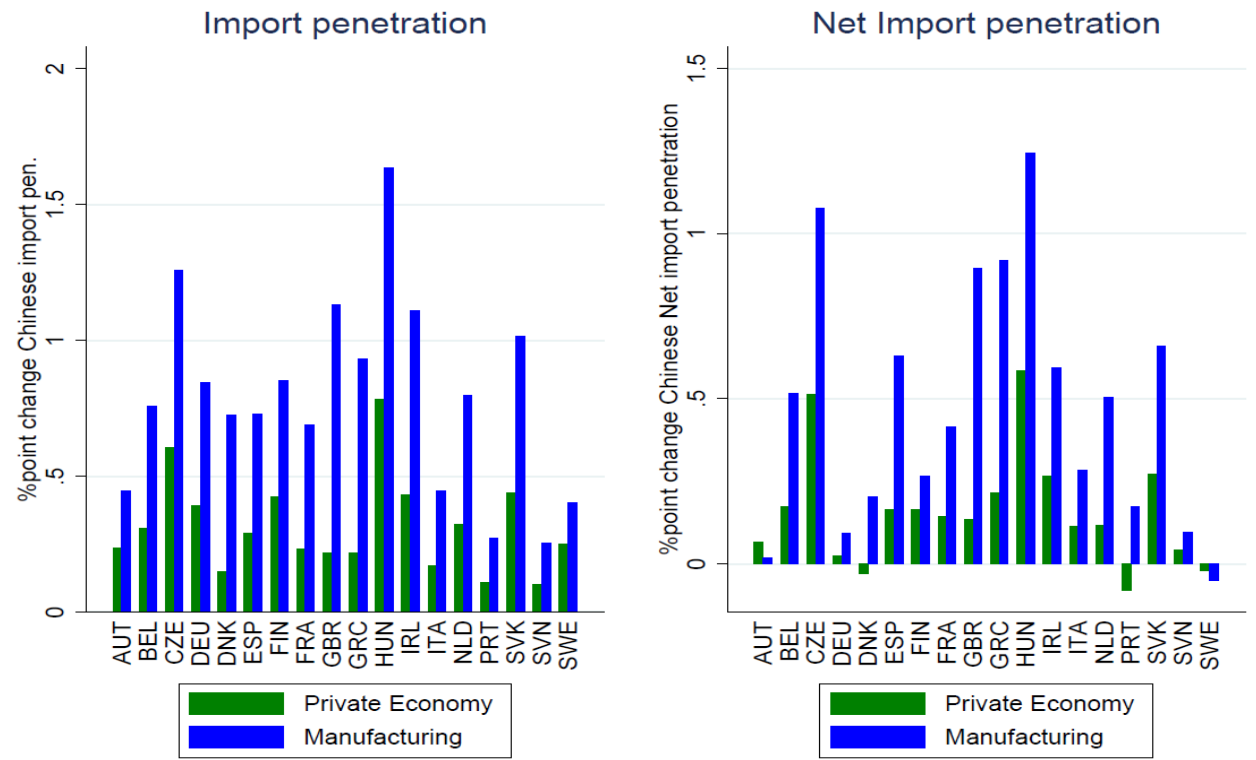

Source: Authors' calculations based on WIOT 


\section{A.3 Summary statistics of regression samples}

Table A2: Summary statistics for variables included in within-sector polarization regressions

\begin{tabular}{|c|c|c|c|c|c|}
\hline & \multicolumn{5}{|c|}{ NACE two-digit Manufacturing sectors } \\
\hline & Observations & Mean & Std.Dev. & Min. & Max. \\
\hline top & 1937 & -1.01 & 0.71 & -4.13 & 1.07 \\
\hline bottom & 1932 & -2.02 & 0.69 & -4.48 & -0.12 \\
\hline $\ln O F F S H$ & 1937 & 3.41 & 0.33 & 2.54 & 4.27 \\
\hline $\ln R \& D$ Intensity & 1937 & 0.55 & 1.52 & -8.01 & 4.43 \\
\hline $\ln I C T$ & 1937 & 0.96 & 1.55 & -2.87 & 7.36 \\
\hline Net Imp.pen ${ }^{C H N}$ & 1937 & 0.72 & 2.66 & -9.62 & 19.21 \\
\hline Union Density & 1937 & 0.36 & 0.22 & 0.08 & 0.81 \\
\hline EPL & 1937 & 0.28 & 0.80 & -1.39 & 1.56 \\
\hline \multirow[t]{3}{*}{ Adjusted Kaitz Index } & 1937 & 0.21 & 0.20 & 0 & 0.59 \\
\hline & \multicolumn{5}{|c|}{ NACE one-digit non-Manufacturing sectors } \\
\hline & Observations & Mean & Std.Dev & Min & Max \\
\hline top & 809 & -0.30 & 0.91 & -2.79 & 2.22 \\
\hline bottom & 809 & -1.21 & 1.39 & -4.23 & 2.99 \\
\hline $\ln \mathrm{OFFSH}$ & 809 & 2.77 & 0.51 & 1.39 & 4.01 \\
\hline In R\&D Intensity & 809 & -1.55 & 1.59 & -8.64 & 1.05 \\
\hline $\ln I C T$ & 809 & -1.78 & 1.52 & -2.63 & 6.86 \\
\hline Net Imp.pen ${ }^{C H N}$ & 809 & 0.04 & 0.34 & -1.87 & 2.89 \\
\hline Union Density & 809 & 0.36 & 0.21 & 0.08 & 0.81 \\
\hline EPL & 809 & 0.31 & 0.74 & -1.39 & 1.58 \\
\hline Adjusted Kaitz Index & 809 & 0.21 & 0.20 & 0 & 0.59 \\
\hline
\end{tabular}

Table A3: Summary statistics for variables included in between-industry reallocation regressions

\begin{tabular}{|c|c|c|c|c|c|}
\hline & \multicolumn{5}{|c|}{ NACE two-digit Manufacturing sectors } \\
\hline & Observations & Mean & Std.Dev. & Min. & Max. \\
\hline$\Delta \ln e m p$ & 139 & -5.5 & 28.99 & -101.07 & 52.59 \\
\hline$\triangle O F F S H$ & 139 & 3.03 & 4.11 & -10.32 & 15.16 \\
\hline$\Delta R \& D I n t e n s i t y$ & 139 & 0.59 & 2.06 & -8.17 & 8.83 \\
\hline$\Delta \ln I C T$ & 139 & 88.18 & 39.52 & -1.16 & 206.97 \\
\hline \multirow[t]{3}{*}{$\Delta$ Net Imp. pen ${ }^{\mathrm{CHN}}$} & 139 & 1.64 & 3.63 & -4.87 & 15.21 \\
\hline & \multicolumn{5}{|c|}{ NACE one-digit non-Manufacturing sectors } \\
\hline & Observations & Mean & Std.Dev & Min & $\operatorname{Max}$ \\
\hline$\Delta \ln e m p$ & 51 & 13.81 & 30.84 & -58.43 & 85.47 \\
\hline$\triangle O F F S H$ & 51 & 2.19 & 4.30 & -9.69 & 13.10 \\
\hline$\Delta R \& D I n t e n s i t y$ & 51 & 0.01 & 0.42 & -1.33 & 1.01 \\
\hline$\Delta \ln I C T$ & 51 & 83.94 & 36.98 & -21.83 & 175.01 \\
\hline$\Delta$ Net Imp. pen ${ }^{\mathrm{CHN}}$ & 51 & 0.03 & 0.30 & -0.63 & 1.13 \\
\hline$\Delta$ Indirect Net Imp. pen ${ }^{\mathrm{CHN}}$ & 51 & 0.24 & 0.27 & -0.07 & 1.43 \\
\hline
\end{tabular}




\section{B Additional robustness checks}

\section{B.1 Construction downstream exposure measure}

We use the methodology of Acemoglu et al. (2015) and Acemoglu et al. (2016) to construct the indirect exposure to downstream Chinese import penetration shocks. We start by aggregating some industries in the WIOD yearly input/output-tables so that the definition of the industries complies with the one used in our regressions. Next, we compute a coefficient $\widehat{a_{\imath \jmath}}$ in the following manner:

$$
\widehat{a_{l \jmath}}=\frac{\text { output }_{i \rightarrow j}}{\text { output }_{i}}
$$

These coefficients capture how important the sales from industry $i$ to industry $j$ are relative to the total output of industry $i$. As the increase in Chinese imports of industry $j$ goods diminish demand for goods of the domestic industry $j$, domestic industry $j$ will in turn reduce its demand of inputs from industry $i$. The greater is the importance of industry $j$ in overall output of industry $i$, the more a shock of industry $j$ is propagated to industry $i$. However, the reduction in demand for industry $j$ goods might also trigger a decrease in demand for inputs from other industries to which industry $i$ in turn provides inputs. Therefore, a reduction in demand for a downstream industry can trigger both direct and indirect reductions in demand for industry $i$ output. We use the Leontief inverse element ${\widehat{a_{l j}}}^{-1}$ to capture all direct and indirect effects on the output of industry $i$ of a reduction in output of industry $j$. Next, we compute the indirect exposure of an industry $i$ to a Chinese import penetration shock as follows:

$$
\text { Ind. Net Imp.pen } n_{t}^{C H N}=100 *\left(\sum_{j}^{J}{\widehat{a_{\imath \jmath, t-1}}}^{-1} \text { Imp.pen }_{i c t}^{C H N}-\sum_{j}^{J}{\widehat{a_{\imath \jmath, t-1}}}^{-1} \text { Exp.pen }_{i c t}^{C H N}\right)
$$

Where industry $i$ is a domestic non-manufacturing industry and industries $j \in J$ are domestic manufacturing industries. The indirect exposure of a non-manufacturing industry is thus equal to the sum of the indirect exposures to Chinese import penetration of each individual manufacturing industry. We use the Leontief inverse element at moment $t^{-1}$ as this has not been affected by the shock in year $t$.

\section{B.2 Additional results}

In table B1 we show the results of interacting OFFSH and Chinese import competition with measures of labor market institutions, such as Union Density, EPL and Minimum Wages. We only analyze specifications without time trend as the labor market institution variables vary at the country-year level. When we account for potential interactions between labor market institutions and each of the different forces affecting employment, the table shows that there are some interactions that turn up significant. High labor union density and employment protection legislation in manufacturing industries that are highly exposed to the force of globalization are associated with more high-paid employment polarization. In non-manufacturing industries we find that higher minimum wages mitigate low-paid job polarization in industries more exposed to Chinese import penetration. Despite these significant interactions, it stands out that generally the interactions are not statistically significant showing that the effects are overall weak.

As an additional robustness check into the relevance of labor market institutions for within-industry polarization we construct an institutional dummy that is equal to one for those countries that satisfy three 
criteria: above median union density, above median employment protection and, finally, above median centralization of wage bargaining ${ }^{26}$. The relevant countries are Belgium, Finland, Italy and Slovenia. The institutional dummy is subsequently interacted with the globalization and technology forces. In this way, we wish to test whether those countries with strong labor market institutions show larger association of globalization and technological change with polarization. Results are presented in table B2. We see that the interactions are generally not significant. Only for low-paid employment polarization in manufacturing industries do we find significant results. However, the two significant interactions have opposite signs, indicating that these are likely capturing other factors.

Table B1: Explaining polarization within-industry polarization in the period 1996 - 2007: Interaction of offshoring measure and Chinese import penetration with labor market institutions

\begin{tabular}{|c|c|c|c|c|}
\hline & \multicolumn{2}{|c|}{ Manufacturing } & \multicolumn{2}{|c|}{ "Non-Manufacturing } \\
\hline & (1) & $(2)$ & (3) & (4) \\
\hline OFFSH & -0.06 & -0.48 & -0.00 & 0.03 \\
\hline$R \& D$ intensity & $0.09 * * *$ & 0.05 & -0.01 & -0.01 \\
\hline ICT & $0.24 * * *$ & 0.10 & $0.18^{* * *}$ & $0.11^{* * *}$ \\
\hline Net Imp.pen ${ }^{\text {CHN }}$ & -0.02 & -0.06 & 0.16 & -0.02 \\
\hline Union Density & $-3.43^{*}$ & -4.29 & -1.93 & -1.76 \\
\hline OFFSH $\times$ Union Density & $1.14 *$ & 1.68 & 0.55 & $0.91 * *$ \\
\hline Net Imp.Pen ${ }^{C H N} \times$ Union Density & $0.08 * *$ & $0.16^{*}$ & -0.07 & 0.18 \\
\hline EPL & -0.45 & -0.54 & 0.00 & 0.21 \\
\hline OFFSH $\times E P L$ & 0.14 & 0.16 & 0.02 & -0.06 \\
\hline Net Imp.pen ${ }^{C H N} \times \mathrm{EPL}$ & 0.00 & -0.03 & -0.07 & 0.07 \\
\hline Adjusted Kaitz index & -0.50 & 0.75 & -0.44 & 0.53 \\
\hline OFFSH $\times$ Adjusted Kaitz index & 0.13 & -0.13 & 0.19 & -0.09 \\
\hline $\begin{array}{l}\text { Net Imp.pen }{ }^{C H N} \times \text { Adjusted Kaitz } \\
\text { Index }\end{array}$ & 0.04 & $0.12 *$ & -0.30 & -0.06 \\
\hline Constant & -1.24 & -1.14 & -0.53 & $-1.42 *$ \\
\hline$N$ & 1937 & 1932 & 892 & 892 \\
\hline Industryxcountry FEs & Yes & Yes & Yes & Yes \\
\hline Country×year FEs & No & No & No & No \\
\hline$R^{2}$ & 0.932 & 0.798 & 0.977 & 0.986 \\
\hline
\end{tabular}

\footnotetext{
${ }^{26}$ We use the variable level from the ICTWSS database of Visser (2015) which reports the predominant level at which wage bargaining takes place.
} 
Table B2: Differences between group of countries with strong institutions

\begin{tabular}{|c|c|c|c|c|}
\hline & \multicolumn{2}{|c|}{ Manufacturing } & \multicolumn{2}{|c|}{ Non-manufacturing } \\
\hline & (1) & (2) & (3) & (4) \\
\hline & Top & Bottom & Top & Bottom \\
\hline OFFSH & -0.13 & -0.55 & -0.05 & 0.28 \\
\hline OFFSH $\times$ Institutions & 0.25 & $1.10^{* *}$ & 0.20 & 0.21 \\
\hline R\&D intensity & 0.04 & 0.01 & -0.01 & 0.01 \\
\hline R\&D intensity $\times$ Institutions & -0.03 & -0.09 & $0.03 * *$ & 0.00 \\
\hline ICT & 0.09 & 0.12 & -0.07 & 0.07 \\
\hline ICT $\times$ Institutions & 0.11 & $-0.40 * * *$ & 0.11 & -0.27 \\
\hline Net Imp.pen ${ }^{C H N}$ & $0.90 *$ & $1.56^{*}$ & -1.25 & 7.68 \\
\hline Net Imp.pen ${ }^{C H N} \times$ Institutions & $1.87 * * *$ & 0.71 & -4.05 & 2.16 \\
\hline Constant & $-0.89 * *$ & -1.35 & -0.37 & $-1.79 *$ \\
\hline$N$ & 2053 & 2048 & 919 & 919 \\
\hline Industry $x$ country FEs & Yes & Yes & Yes & Yes \\
\hline Ctry $\times$ Year FEs & Yes & Yes & Yes & Yes \\
\hline$R^{2}$ & 0.955 & 0.906 & 0.989 & 0.989 \\
\hline
\end{tabular}

Table B3: patents/employee as alternative measure of process and product innovation in manufacturing industries

\begin{tabular}{|c|c|c|c|c|c|c|c|c|}
\hline & (1) & (2) & (3) & (4) & (5) & (6) & (7) & (4) \\
\hline & top & bottom & top & bottom & top & bottom & top & bottom \\
\hline OFFSH & $0.36^{* *}$ & 0.02 & -0.08 & -0.24 & $0.43 * *$ & 0.07 & -0.06 & -0.25 \\
\hline $\mathrm{R} \& \mathrm{D}$ intensity & $0.09 * * *$ & 0.06 & 0.03 & -0.01 & & & & \\
\hline Patent/employee & & & & & 0.07 & 0.02 & 0.04 & 0.04 \\
\hline ICT & $0.25^{* * *}$ & 0.11 & $0.13 * *$ & 0.00 & $0.25 * * *$ & 0.12 & $0.13 * *$ & 0.00 \\
\hline Net Imp.pen ${ }^{C H N}$ & $0.02 *$ & 0.01 & $0.01 * *$ & 0.02 & $0.02 *$ & 0.01 & $0.01 * *$ & 0.02 \\
\hline Union Density & 0.33 & 1.26 & & & 0.56 & 1.35 & & \\
\hline EPL & 0.01 & -0.01 & & & 0.01 & -0.01 & & \\
\hline Adjusted Kaitz Index & -0.07 & 0.31 & & & -0.13 & 0.27 & & \\
\hline Constant & $-2.64 * * *$ & $-2.80 *$ & -0.84 & -1.23 & $-3.16 * * *$ & $-3.03 * * *$ & $-1.05^{*}$ & -1.41 \\
\hline $\mathrm{N}$ & 1937 & 1932 & 2053 & 2048 & 1937 & 1932 & 2053 & 2048 \\
\hline Industry $x$ country FEs & Yes & Yes & Yes & Yes & Yes & Yes & Yes & Yes \\
\hline Year FEs & No & No & Yes & Yes & No & No & Yes & Yes \\
\hline$R^{2}$ & 0.930 & 0.792 & 0.954 & 0.905 & 0.929 & 0.792 & 0.954 & 0.905 \\
\hline
\end{tabular}


Table B4: Separating import penetration from China and export penetration to China in two separate measures - Manufacturing industries

\begin{tabular}{|c|c|c|}
\hline & $\begin{array}{l}\text { (1) } \\
\text { top }\end{array}$ & $\begin{array}{c}\text { (2) } \\
\text { bottom }\end{array}$ \\
\hline OFFSH & -0.112 & -0.271 \\
\hline R\&D intensity & 0.032 & -0.011 \\
\hline ICT & $0.135^{* * *}$ & 0.014 \\
\hline Imp.pen ${ }^{C H N}$ & 0.023 & 0.065 \\
\hline Exp.pen. ${ }^{C H N}$ & -0.005 & -0.019 \\
\hline Constant & -0.643 & -1.001 \\
\hline $\mathrm{N}$ & 2053 & 2048 \\
\hline Industry $\times$ country FEs & Yes & Yes \\
\hline country $\times$ Year FEs & Yes & Yes \\
\hline$R^{2}$ & 0.954 & 0.905 \\
\hline
\end{tabular}

Table B5: Testing impact of downstream exposure to Chinese import penetration in non-manufacturing industries

\begin{tabular}{lcccc}
\hline & $(1)$ & $(2)$ & $(3)$ & $(4)$ \\
& top & bottom & top & bottom \\
\hline OFFSH & 0.26 & $0.29 * *$ & 0.01 & 0.30 \\
R\&D intensity & -0.00 & -0.02 & -0.01 & 0.01 \\
ICT & $0.19^{* * *}$ & $0.14^{* * *}$ & -0.05 & 0.01 \\
Net Imp.pen ${ }^{C H N}$ & 4.77 & 7.75 & -1.55 & 8.44 \\
Indirect Net Imp.pen. ${ }^{C H N}$ & 0.08 & 0.09 & -0.02 & -0.08 \\
Union Density & -0.59 & 0.81 & & \\
EPL & 0.06 & $0.06^{*}$ & & $-1.60^{* *}$ \\
Adjusted Kaitz index & 0.07 & 0.18 & & 919 \\
Constant & -1.17 & $-2.16^{* * *}$ & -0.38 & Yes \\
\hline \hline N & 892 & 892 & 919 & Yes \\
Industry $\times$ country FEs & Yes & Yes & Yes & 0.989 \\
country $\times$ Year FEs & No & No & Yes \\
$R^{2}$ & 0.977 & 0.985 & 0.989 & \\
\hline \hline
\end{tabular}

${ }_{p}^{*}<0.10,{ }^{* *} p<0.05,{ }^{* * *} p<0.01$

Indirect Net Imp.pen ${ }^{C H N}$ is the downstream exposure to net import penetration from China through the industrial links with domestic manufacturing industries. Net Imp.pen ${ }^{C H N}$ is expressed in levels rather than $\operatorname{logs}$. For ease of interpretation of the coefficient on Net Imp. pen ${ }^{C H N}$ and Indirect Net Imp.pen ${ }^{C H N}$, the dependent variable in columns (5) to (8) is 100 times the log change in top or bottom polarization. 


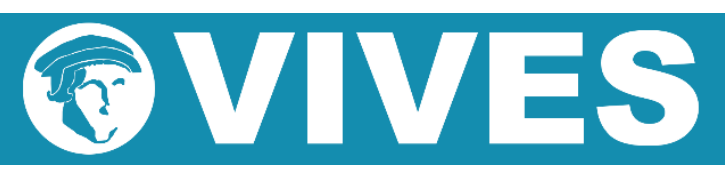

Research Center for Regional Economics

Waaistraat 6 - bus 3550

3000 Leuven, Belgium

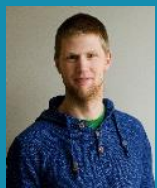

\section{Koen Breemersch \\ VIVES (KU Leuven) \\ koen.breemersch@kuleuven.be}

\section{Jože P. Damijan}

University of Ljubljana; and VIVES (KU Leuven)

joze.damijan@ef.uni-lj.si

\section{Jozef Konings}

VIVES (KU Leuven); Nazarbayev University; and University of Ljubljana joep.konings@kuleuven.be

Copyright @ 2017

Discussion papers are in draft form. This discussion paper is distributed for purposes of comment and discussion only. It may not be reproduced without permission of the copyright holder.

An electronic version of the discussion paper is available on the VIVES website:

http://www.feb.kuleuven.be/VIVES 